University of San Diego

Digital USD

1992

\title{
The Impact of the Accountability Movement on Principals in a Large Southern California School District
}

Dianette T. Mitchell EdD

University of San Diego

Follow this and additional works at: https://digital.sandiego.edu/dissertations

Part of the Leadership Studies Commons

\section{Digital USD Citation}

Mitchell, Dianette T. EdD, "The Impact of the Accountability Movement on Principals in a Large Southern California School District" (1992). Dissertations. 577.

https://digital.sandiego.edu/dissertations/577

This Dissertation: Open Access is brought to you for free and open access by the Theses and Dissertations at Digital USD. It has been accepted for inclusion in Dissertations by an authorized administrator of Digital USD. For more information, please contact digital@sandiego.edu. 


\section{THE IMPACT OF THE ACCOUNTABIIITY MOVEMENT ON PRINCIPALS}

IN A LARGE SOUTHERN CALIFORNIA SCHOOL DISTRICT

by

Dianette T. Mitchell

A dissertation submitted in partial fulfillment of the requirements for the degree of Doctor of Education

\section{University of San Diego}

1992

\section{Dissertation Committee}

Joseph C. Rost, Ph.D., Director

Edward Kujawa, Jr., Ph.D.

Sharon Whitehurst, Ph.D. 


\begin{abstract}
THE IMPACT OF THE ACCOUNTABILITY MOVEMENT ON PRINCIPALS IN A LARGE SOUTHERN CALIFORNIA SCHOOL DISTRICT
\end{abstract}

MITCHELL, DIANETTE T., Ed.D., University of San Diego, 1992, $133 \mathrm{pp}$.

Director: Joseph Rost, Ph.D.

Organizations achieve uniqueness in their functions despite similarities in their structure. This uniqueness is true of school districts as well. Though there are specific similarities which have been found in effective schools and districts who have joined the accountability movement, each has its own systematic method of modifying and controlling desired behavior and possible achievement.

This research focuses on one unique group of people, the site administrators in a large school district, and seeks to ascertain the effects of the effective schools' accountability movement as seen from the perspective of school principals.

The three major objectives of this study were to determine the impact of the accountability movement on principal behavior, the changes it has had on the role of the school principal, and to identify areas of skill and knowledge that today's principals must possess or actively pursue in order to be effective instructional administrators. 
This research utilized both qualitative and quantitative methodologies to discern the impact of the accountability movement from the perspective of $\mathrm{k}-12$ administrators. A Likert-like scale survey questionnaire which incorporated open-ended questions was designed to elicit j.nformation pertinent to research objectives. In addition, personal interviews were conducted to allow for dialogue and indepth understanding of the movement, its impact, and the changes it has brought with it. The results of this study indicate that the accountability movement has indeed had an impact on the role of principals and provide an evolutionary picture of the movement within the district under study. 
- 1992

by

Dianette T. Mitchell

All Rights Reserved

Reproduced with permission of the copyright owner. Further reproduction prohibited without permission. 


\section{DEDICATION}

To my beloved mother, Edna saxton,

for teaching me how to turn life's challenges

into stepping stones.

ii

Reproduced with permission of the copyright owner. Further reproduction prohibited without permission. 


\section{ACKNOWLEDGEMENTS}

The completion of this doctoral program is truly a dream come true. An undertaking of this magnitude causes one to wonder if the desired outcome can really be achieved. I wish to express my sincere and deepest appreciation to the members of my dissertation committee, Dr. Edward Kujawa and Dr. Sharon Whitehurst, who were there for me with words of encouragement whenever I was in need. A special thanks goes to my committee chair, Dr. Joseph Rost, who has made the completion of this dissertation possible because of his continued belief in me and his helping me extend and grow.

I will always be indebted to my friend and colleague, Dr. Lyle Rangel, for his monthly phone calls which kept me focused on my project goal.

I must also thank my family, Aunt Rozelia, Aunt Geraldine, my daughter, Myesha, my former spouse, willie, and other loved ones who consistently supported me during the many years that I took completing this research project. Finally, I give thanks to God, who has been with me each step of the way. 
TABIE OF CONTENTS

PAGE

IIST OF TABLES . . . . . . . . . . . . . . . . vii CHAPTER

I. STATEMENT OF THE PROBLEM . . . . . . . . . 1

Introduction ............... 1

Background: Effective, Accountable

Schools Movement .. . . . . . . . 1

The Issue . . . . . . . . . . . . 14

Objectives of This Research . . . . . . 16

Significance of the study . . . . . . 17

Definition of Terms . . . . . . . . 17

II. REVIEW OF THE LITERATURE . . . . . . . . 20

Effective Schools and Principals . . . 20

Accountability . . . . . . . . . 28

Summary . . . . . . . . . . . . 4 41

III. RESEARCH DESIGN AND METHODOLOGY . . . . . . 42

Introduction . . . . . . . . . . . 42 42

Research Methodology . . . . . . . 43

Data Gathering . . . . . . . . . 43

Survey Instrument . . . . . . . . 43

Data Analysis . . . . . . . . . . 50

Survey Questionnaire . . . . . . . 50

Interviews . . . . . . . . . . 51

iv 
Iimitations of Study . . . . . . . . 52

Summary . . . . . . . . . . . . 52

IV. ANALYSIS OF EDUCATIONAL ACCOUNTABILITY

MOVEMENT DATA . . . . . . . . . . . 53

Demographic Analysis of the

Respondents . . . . . . . . . . . 54

Analysis of the study . . . . . . . 59

Impact of Accountability on

Principal Behavior .. . . . . . 59

The Changing Role of the Principal . . . 63

Skills and Knowledge for Today's

Principals . . . . . . . . . 73

Additional Questionnaire Summaries . . . 74

Interview summaries . . . . . . . . 92

Events Leading to the Accountability

Movement Within the District . . . . 92

Drawbacks Encountered in Implementing

Changes Associated with the

Effective Schools Research . . . . 93

Definition of an Instructional

Leader . . . . . . . . . . . . 94

Time spent by Principals observing

Teachers and Planning Curriculum . . 95

The Impact of the Accountability

Movement on Principals . . . . . . 96

Problems Principals Encounter with

the Implementation of the

Superintendent's objectives . . . . 98

Changes in the Role of the Principal

in the Last Three Years ..... . 98

Kind of Knowledge or Skill Paramount

for Today's Principal ....... . 99

Participant Responsibility for the

Educational Process ........ 100

$\mathbf{v}$ 
Holding Participants Responsible for the Educational Process . . . . 101

Defining and Measuring Results . . . . 101

Determining Participants' Contribution . . . . . . . . . 102

Consequences for Educators . . . . . 102

Merit Pay for Teachers . . . . . . . 102

Merit Pay and Senate Bill 813 . . . . 103

Making Site Administrators More Effective ............ 103

V. SUMMARY, CONCLUSION, AND RECOMMENDATIONS . . 106

Summary . . . . . . . . . . . 106

The Purpose .. . . . . . . . 106

Research Design . . . . . . . 107

Results ............... 108

Conclusions and Discussion . . . . . . 110

Recommendations for Further Study . . . 116

Concluding Remarks .. . . . . . . 117

REFERENCES . . . . . . . . . . . . . . . . 119

APPENDIX A: PRINCIPAL QUESTIONNAIRE . • . . . . . 127

APPENDIX B: LETTER OF TRANSMITTAL TO

FIELD TEST PARTICIPANTS . . . . . . . . . . . 131

APPENDIX C: IETTER OF TRANSMITTAL TO

PRINCIPALS . . . . . . . . . . . . . . 132

APPENDIX D: INTERVIEW QUESTIONS . . . . . . . . 133

vi 


\section{IIST OF TABLES}

TABLE

PAGE

1. Survey Questions and Subject Areas . . . . 54

2. Geographical Locales of the Respondents .............. 55

3. Categorical Programs at the 40 Schools . . 58

4. Ethnicity of the Respondents . . . . . . 59

5. Higher organizational Expectations and Pressure to Perform . . . . . . . . 60

6. Accountability for student Achievement .............. 61

7. To What Extent Has the Impact of the Accountability Movement Affected You as a Principal Becoming an Instructional Leader . . . . . . . . .

8. Pressure to Become an Instructional

Leader . . . . . . . . . . . . . .

9. The Problems Encountered in Creating and Maintaining an Effective School: Lack of Central office Support and Funding .................

10. The Problems Encountered in Creating and Maintaining an Effective School: Teacher Observation/Clinical Teaching Too Time Consuming

11. The Problems Encountered in Creating and Maintaining an Effective School: Uncooperative Teachers or Teachers Needing Technical Assistance .. . . .

12. The Problems Encountered in Creating and Maintaining an Effective School: Lack of Parent Participation . . . . . 
13. Should Administrative Results/Success

Be Measured by Administrator

Evaluation Form? . . . . . . . . . . .

14. Should Administrative Results/Success Be Measured by Student Achievement

on CTBS? . . . . . . . . . . . . . .

15. Should Administrative Results/Success

Be Defined by CAP Test Scores? . . . . .

16. Should Administrative Results/Success

Be Measured by Program Quality

Review Outcomes?

17. Problems Encountered in Creating and Maintaining an Effective School

18. Knowledge and Skills Needed by Today's Principal

19. The knowledge Paramount for Today's Principal

20. Teacher Responsibility for Making the Educational Process Functional . • . 77

21. Principal Responsibility for Making Educational Process Functional

22. To What Extent Should Principals Be Held Accountable for Making the Educational Process Functional?

23. Central Office Staff Responsibility for Making Educational Process Functional

24. The Accountability Movement in the District Has Resulted from the . . . .

25. Site Administrative Results Should

Be Defined and Measured . . . . . . . .

26. Question 21: Characteristics of an Instructional Leader . . . . . . . .

27. Question 23: Suggested Consequences for Professional Educators Including Administrators Who Are Unable to Achieve Agreed Upon Results in Student Learning 
28. Question 24: What Would You Have to Change in order to Make Your Site an Even More Effective School? 
CHAPTER I

STATEMENT OF THE PROBLEM

\begin{abstract}
Introduction
Organizations achieve uniqueness in their functions despite similarities in their structure. This uniqueness is true of school districts as well. Though there are specific similarities which have been found in effective schools and districts who have joined the accountability movement, each has its own systematic method of modifying and controlling desired behavior and possible achievement.

This research focuses on one unique group of people, the San Diego Unified School District's site administrators, and seeks to ascertain the effects of the effective schools' accountability movement as seen from the perspective of school principals.
\end{abstract}

\title{
Background: Effective, Accountable
}

Schools Movement

The demand for educational accountability and equitable educational opportunities for all students has escalated research in the areas of effective schooling and educational accountability. Another catalyst which accelerated research in areas of effective schooling and educational accountability was the study initiated by the United states office 
of Education's National Center for Educational statistics directed by James S. Coleman, Professor of Social Relations at Johns Hopkins University. The Coleman report asserted that the crucial factor in evaluating equality of educational opportunity was the home and family background of children. Superior schools drew their students from a predictably superior pool of children and families; therefore, gaps among students already existed when children first entered school. Coleman further postulated that school influences did very little to close existing gaps which implied that academic achievement was only minimally related to school policies and resources (Coleman et al., 1966). This attack on schools was reiterated in a study by Jencks et al. (1972), whose conclusions were congruent with the previous findings of the coleman report. These findings would later come under the scrutiny of such researchers as Brophy and Enertson (1974) and Brookover and Lezotte (1979), whose findings suggested that schools do make a difference in the cognitive learning of students. Later research by Coleman, Hoffer, and Kilgore (1982) revealed differences among public and private schools. Private schools were found to have more rigorous subjects and more homework than their counterparts. Here, Coleman and his associates appear to be somewhat in agreement with other effective schooling studies. Though he labeled private schools as superior to public schools, he also appeared to recognize that in 
setting priorities and adhering to them, schools can and do make a difference (Coleman et al., 1982).

As educational debates continued throughout the nation, educational organizations continued to be under great scrutiny. This, too, held true for the San Diego Unified School District.

On December 4, 1967, a complaint was filed in the Superior court of the state of California challenging the efforts of the San Diego Unified School District for its failure to take feasible steps to alleviate desegregation of the city's schools. This case, Carlin v. Board of Education (1967), continued for nearly 10 years. The plaintiffs in the Carlin case claimed that the district had been "intractable, recalcitrant, and stubbornly opposed to desegregation" (p. 3).

On March 9, 1977, the superior court in its ruling on the Carlin case found 23 schools in the district that could be considered segregated as defined by crawford $v$. Board of Los Angeles (1976). This decision initiated the court's involvement in the operation of the school district.

The Honorable Judge Louis $M$. Welsh charged then superintendent, Thomas Goodman, with the responsibility of creating an Integration Task Force which was to be made up of individuals dedicated to the desegregation of the school district. Welsh stated that he desired the creation of quality programs designed to integrate, not just desegregate. The court would annually review district 
progress, and, in fact, Judge Welsh remained vigilant in this area for several years.

According to Goren (1984), Welsh's persistence in this case came in the form of memoranda of intended decisions, and yearly charges to the Integration Task Force, which was appointed by the court. The task force's charge was to monitor, analyze, and evaluate the quality and methods of education in all minority isolated schools. The progress reports that Welsh received from the task force enabled him to evaluate the district's actual progress toward integration. His dissatisfaction with the integration plans of the district was evident in his December "Order Re: Integration Plan of 1980-81" (1980), which required the board of education to undertake a study of the administrative structure of the school district. The order stated that the board of education should:

With the help of outside assistance from persons or organizations approved by the court, undertake a study of the administrative structure and organization of the School District to redesign such structure so that it will be responsive to the educational needs of the students, better able to detect both superior and inferior performance in the classroom, improve communications for the purpose of replicating outstanding programs and discontinuing ones that are not productive and for facilitating the supervision and monitoring of school principals and classroom teachers. (p. 25) 
The order included a request for written evaluations from the task force. The first such report, entitled organization study of the San Diego Unified School District (1981), was presented to the court and the school district on March 17, 1981. The findings of the report included 22 recommendations; however, the report did not recommend any major organizational change. The proposed revisions were to rectify concerns voiced by the board of education which was headed by then president, Yvonne Larsen.

Prior to the organization study of the decision-making process, the time it took to gain approval from the superintendent to board had been slow and the communication processes within the district office and school sites lacked coordination. These problems caused the administrators at the schools to generate duplication of information.

of major concern was the lack of use of community Relations and Integration Services, a division in the district office which was set up to monitor schools and their integration efforts. School sites were in need of central office support and the recommendation was made that Community Relations and Integration Services be expanded to include assistance to school site personnel implementing new or improved desegregation programs. The task force indicated eight schools were totally minority isolated.

Solving the problem of minority isolated schools made it necessary for the district to look at the racial/ethnic compositions of student enrollments on a school by school 
basis. Facilitation of the district's Voluntary Ethnic Enrollment Program (VEEP) and provision of quality education to minority isolated students became paramount. In addition, planning and articulation between elementary and secondary groupings of schools based on feeder school patterns were to be implemented to create a smoother progression for students as they matriculated from the elementary to the secondary level. Administrative procedures were to be established which would reflect a $\mathrm{k}-12$ continuum of services to schools insuring equitable treatment of all programs regardless of grade levels.

An examination of the roles and responsibilities of the board members and district line officers was to be conducted to clearly define and delineate responsibilities. The board of education was, therefore, asked to review and concisely define its goals, the direction and the priorities it wished to pursue. To this end, the board was to meet with selected employee group representatives to collectively define roles and responsibilities and board/staff relationships. The purpose of this process was to build a much needed trust between the board and staff as soon as possible.

The board of education accepted the task force report and responded positively to its recommendations. However, the implementation of the recommendations proposed by the court and the task force was the responsibility of the superintendent. 
Goren (1984) stated that Judge Welsh continually faced what he considered to be a lack of commitment from school district administrators to implement an integration program. The judge was convinced that voluntary integration programs would avoid the types of problems that would arise from the enforcing of a mandatory busing program. Goodman, who was charged in the Carlin case with being insensitive to the needs of the minority community, would not respond to the judge's orders. This controversy caused the superintendent to be under the close scrutiny of Judge Welsh's court (Goren, 1984, pp. 27-28).

In April, 1981, the superintendent's actions were challenged further as a testing scandal involving the Achievement Goals Program (AGP) erupted. The AGP program was designed to improve the test scores of minority students through the use of directed teaching strategies and district developed materials which provided systematic reinforcement in basic learning deficiencies. AGP would later prove to be a fine program. However, in 1981, a discovery was made in the testing and evaluation of the district. The AGP program was using questions which came directly from the California Test of Basic Skills (CTBS) achievement tests which would improperly skew test score results. An investigation indicated that only a few administrators in the district office were responsible for all district educational programs. The superintendent and three other administrators were given a reprimand by the board for their negligence and 
improper supervision of the testing program. The testing scandal proved to be the "the straw that broke the camel's back," and was the major impetus for the administrative reorganization of the San Diego City Schools.

The board of education began the reorganization process by creating the San Diego City Schools Task Force to Study the Organizational Structure in the San Diego Unified School District. Representatives from the district office, the San Diego County office of Education, the San Diego City Schools Administrator's Association, and the community studied district administrative reorganization. The task force was charged with developing an administrative structure which addressed the needs of the 23 racially isolated schools. Goodman refused to serve on this committee.

On August 3, 1981, Welsh in his annual "Memorandum of Intended Decision" appointed three school administration specialists to study how the district could be reorganized. The court appointed experts were Ewald Nyquist, Vice President of Pace University in New York; Michael Kirst, Professor of Education at Stanford University; and H. Thomas James, Director of the Spencer Foundation.

As time passed, both task forces kept Welsh abreast of their endeavors through regular progress reports. Recommendations indicating the need for decentralization or a $\mathrm{K}-$ 12 conterminous restructuring in which elementary, middle and high schools would be put together into areas with common boundaries, and the development of a district 
planning function which could predict trends and impacts were included, along with others, in the progress reports. During this time, tension between the board of education and superintendent Goodman was mounting as the board's demand for knowledge through regular communication with Goodman escalated. The possession of knowledge is often equated with the possession of power for it is difficult at best to take actions necessary to make long-range plans, decisions and policies when access to pertinent information is limited. In limiting the board's scope, the position of power became skewed and trust level diminished. The district appeared to be in upheaval as rumors of trouble spread to school sites bringing with them an air of instability. Employees wondered what was to happen next. They had grown used to the status quo, and change is a process that is easy only when others are asked to do it. Nonetheless, change was imminent and everyone wondered how it would affect them. San Diego Unified was once again in an era of accountability in which the needs of society are reflected through its elected board officials.

Tension continued to mount between the board and superintendent Goodman and reached a peak during the last week of September, 1981. Goodman's refusal to lead the task force on the reorganization of the district had upset the board, and the press indicated that several board members had met with Goodman to discuss a buy-out of his contract (colvin, 1981). 
The board met confidentially with Goodman for nearly two weeks. At the end of the deliberations, Goodman decided not to accept the buy-out offer presented him. The board countered with an attempt to demote Goodman to the role of deputy superintendent but subsequently agreed to allow him to remain in his position on a probationary basis for eight months with the stipulation that several action plans be prepared and implemented to rectify many of the problems cited by the court and task forces.

Judge Franklin B. Orfield took over the responsibility for the Carlin case after Welsh retired from the bench and continued to press the district toward the implementation of a more responsive administrative structure.

Goren (1984) summarized the final month of Goodman's tenure as superintendent:

A movement towards definite change in the school district finally occurred in late February of 1982. The second report of the school district's Task Force was presented on February 16. This was followed by the final report of kirst, Nyquist, and James on February 23 and the resignation of superintendent Thomas Goodman on February 28, 1982. (p. 39)

Goodman's resignation included a $\$ 122,000$ buy-out of the remaining portion of his contract. The superintendent's resignation allowed the board to begin the implementation of its own policy objectives and those ordered by the court. The search for a new superintendent who would work closely 
with the board to change the administrative structure and be responsive to the community was undertaken, and Eugene F. Brucker, Assistant superintendent of student services Division, stepped in to provide organizational stability as acting superintendent.

The effects of Proposition 13 were beginning to be realized and resulted in cutbacks in all governmental services. The school district became concerned that state aid would be reduced, and the board directed the acting superintendent on June 22, 1982 to reduce the management services for $1983-84$ by a minimum of $\$ 750,000$.

On August 6, 1982, Dr. Thomas Payzant was hired as the new superintendent of the San Diego Unified School District. Payzant had not officially taken office when he presented his proposed reorganization concept paper to the board of education on October 8, 1982. Taking a strong stand, he acknowledged that with reorganization there would be change, speculation, and anxiety about the impact and the change it would have on people. Payzant clarified that some existing positions would be eliminated or reassigned while some new positions would be created and asked for board authorization to notify top level administrators who were on fixed time contracts that automatic contract renewal would not be guaranteed in the new organization, but they would be given fair consideration for positions in the school district for which they qualified. A clear deinition of his personal philosophy was given in his paper: 
A school district exists to provide educational services for children. In form and function, the administrative organization is designed to meet the goals of the school district. The final test of the organization's effectiveness is whether it works. Is it responsive to the people it serves? Will it foster planning, decision making, implementation of programs, and evaluation? Does it accommodate diversity, conflict, and creativity? Will it encourage commitment, effort and caring? Can it tolerate determination, risk taking and questioning? Does it encourage its employees to be tough, but not insensitive; decisive, but fair; and idealistic, but realistic?

My goal is an organization that provides positive answers to these questions. It will require a central office staff able to cut red tape and extend services to the teachers, administrators, and support personnel who work directly with children in the schools. The organization must create a balance between direction from the central office and autonomy in individual schools. There must be a clear understanding of where responsibility lies. There must be a balance between district goals and school goals, between district standardization and school flexibility. The administrative organizational plan I present here is designed to be functional, cost effective, and service oriented. It will require competent, committed, diligent people 
working through it to meet the policy goals set by the Board and the administrative objectives set by me. (Payzant, 1982, pp. 1-2)

The plan presented for reorganization and consolidation was concise. The district needed to strive for centralized direction that established continuity and equity, but which supported some decentralization by encouraging staff and parent involvement in decision making at the building level. The proposed organization, which later became reality, was to have six major divisions: Finance; School operations; Business Services; Educational Services; Personnel Services; and Planning, Research and Evaluation. Roles and expectations were delineated for each division with chain of command and lines of communication. In summary, Payzant reaffirmed his philosophy of why organizations exist and how they achieve their desired results in his statement:

An organization exists to help people achieve specific purposes. It defines where authority and responsibility must be. It sets expectations. One form of organization can be better than another, but in the final analysis, it is the people who fill the roles in the organization that determine whether or not purposes are achieved. (Payzant, 1982, pp. 4-18) Payzant officially began his duties as superintendent of the district on November 1, 1982 and on November 2, 1982, he received board approval for his plan. During the interim period between November, 1982, and May-June, 1983, decisions 
regarding appointments, promotions, demotions and reduction in management staff took place as Payzant carried out the board directive of June 22,1982 . The board adopted district goals for 1983-85 on May 31, 1983. The 1983-84 objectives of the superintendent were stated for each board goal. These goals and objectives constituted the expectations held by the board and the superintendent for the district, the direction that employees were to take in meeting position responsibilities, a plan for allocation of resources and a plan for evaluation of programs and personnel.

Goals and objectives were set in the areas of basic skills, management and organization, facilities planning and budget and finance. The overall district focus was to provide all children the opportunity to reach their potential by enabling them to become literate through setting standards which demanded excellence in the implementation of effective programs, staff development and parent participation. It was the first time that district goals were disseminated and a clear mission set.

\section{The Issue}

Despite past movement toward accountable, effective, efficient schools and the expenditure of billions of dollars allocated to supplement education and its enrichment, many students have not achieved academically according to their potential. National concern for student achievement and 
academic literacy has become a call for educational reform. The need to rectify educational inadequacies has escalated efforts toward educational accountability. The word accountability raises many questions and we begin to ask: (a) What is accountability? (b) Who is accountable? (c) Why have previous attempts at accountability failed? and (d) What part does accountability play in the principalship? In answer to these questions I employ the definition of accountability given by Lopez (1970). He suggested that accountability refers to the "process of expecting each member of an organization to answer to someone doing specific things according to specific plans and against certain timetables to accomplish tangible performance results" (p. 65). This definition of accountability assumes that everyone who joins an organization does so presumably to help in the achievement of its purpose. The definition assumes that individual behavior which contributes to this purpose is functional and that which does not is dysfunctional. Accountability is intended, therefore, to insure that the behavior of every member of an organization is largely functional. Accountability attempts in the past may have failed because there has been little insurance that the behavior of every member of educational organizations is functional.

The principal, as site administrator, is directly responsible for policy program implementation at a specific school which may include but is not limited to academic 
programs. While principal accountability is not a new concept, it has taken on a new meaning, causing change in the level of principal responsibility. This and other changes caused by the accountability movement have impacted principal leadership behavior as well as administrative practice and expectations. In fact, because there have been so many changes, the principalship itself is now in a constant state of change.

\section{objectives of This Research}

The San Diego Unified School District is one of the five largest urban school districts in the state of california and is responsible for the education of thousands of children. This study of educational accountability and its impact on school administrators has three major objectives:

1. To ascertain what impact the educational accountability movement has had on the behavior of selected principals in the San Diego Unified School District from 1983 to 1986 .

2. To determine what changes, if any, the movement toward accountable, effective, efficient schools has had on the role of principals in the San Diego Unified School District from 1983 to 1986.

3. To identify from the principal's point of view areas of skill and knowledge that today's principals must possess or actively pursue in order to be effective instructional administrators. 


\section{Significance of the study}

History supports the fact that many efforts toward educational accountability have been made. Most recently, however, some people have come to the realization that accountability is a fluid and fast moving field which may be culturally and socially bound, depending on the society and its wants and needs. Schools as public agencies are affected by their societal clientele and appear to be under more scrutiny than ever before. The completion of this study will be highly beneficial to both current and prospective administrators, as this study will provide an evolutionary picture and facilitate the understanding of the accountability movement within the district under study. In addition, this study will identify the skills that today's effective leaders must possess.

\section{Definition of Terms}

ABC Schools: These schools are located in communities that have positive ethnic balances.

Achievement Goals Program: A curriculum that focuses on four concepts: mastery learning, direct instruction, time-on-task, and reduced classroom distractions.

Bilingual Programs: A curiculum that provides assistance to the limited English proficient student through English as a second language instruction and instruction in the native language. 
Chapter II Program: A federal program that provides funding for certificated teachers who work in a tutorial capacity for 20 hours per week assisting students in need of additional support.

ECIA Chapter I and State Compensatory Education

Programs: These provide additional support for educationally disadvantaged youth.

Effective School: A school which meets the academic and social needs of its students through strong instructional leadership and rigorous curriculum.

Feeder School: A residential school whose students automatically feed into another residential school.

Gifted and Talented Program: Academically able students are placed in these classes based on screening and certification, high achievement scores and/or teacher recommendation.

Instructional Leadership: The extent to which the site administrator demonstrates commitment and provides practical guidance through vision to his or her staff in the achievement of shared goals.

Magnet School: A magnet school offers a program that has a specialized emphasis, unique and different from those in other schools.

School Improvement Program: A state-funded program started in 1977 which provides framework and funds for the systematic improvement of selected schools and requires periodic program reviews for continued funding. 
Voluntary Ethnic Enrollment Program: A bussing program that allows nonwhite children to voluntarily enroll in a school located in a predominantly white residential area and vice versa. 
CHAPTER II

REVIEW OF THE IITERATURE

This chapter focuses on literature surrounding effective schools and serves to provide an indepth awareness of the research, related to the effective schools/accountability reform movement, as they relate to and affect school administrators.

In the early stages of this review, it became apparent that studies pertaining to effective schools were plentiful while studies pertaining to the accountability reform movement were just beginning to emerge. Encompassing many sources and strategies, this literature search included the use of the ERIC clearinghouse on educational leadership and effective schools. Professional journals, abstracts, periodicals, books, microfilms and dissertations were researched at the University of San Diego, San Diego State University and University of California at San Diego libraries.

\section{Effective Schools and Principals}

With the move toward effective schooling and accountability came the move toward stronger and more effective principals. Administrators need to be knowledgeable in many 
areas in order to be effective in a changing educational organization.

Edmonds (1979) observed that instructionally effective inner city schools had a strong emphasis on acquisition of reading skills and frequent evaluation of pupil progress. In comparison to lower achieving schools, teachers in higher achieving schools reported significantly greater amounts of principal support and were more task oriented. Edmonds, therefore, concluded that the most tangible and indispensable characteristics of effective schools were: (a) strong administrative leadership, (b) a climate of expectation in which no children are permitted to fall below minimum but efficacious levels of achievement, (c) emphasis on acquisition of basic skills, and (d) flexibility of resources to meet fundamental objectives (pp. 20-24). According to Austin (1979), Benjamin (1981), Blumberg and Greenfield (1986), Clark, Lotto, and McCarthy (1980), Gersten and Carnine (1982), Lipham (1982), and shoemaker and Fraser (1981), today's principals need to be knowledgeable and skilled as educational leaders. Each author mentioned the importance of knowledge in at least two or three of the following areas: (a) curriculum and instruction development, (b) interpersonal human relations and cultural awareness, and (c) administration and decision making.

Cawelti (1980) believed that there were two fundamental components which were crucial to effective principals. They are as follows: 
1. Task behaviors, goals which the principal utilizes to put more structure into the work environment.

2. Relationship behavior, goals which the principal employs to motivate people, such as praise, criticism, "strokes," and two-way communication (Cawelti, 1980, pp. 2-5). Effective administrators are those who apply the right mix of concern for goals and people, for they seem to know what kind of behavior is needed. "Situational leadership fits nicely here," Cawelti stated, "in that it teaches that the leader relies heavily upon group maturity as an important determinant of style. . . Today's instructional leaders must possess skills in the four areas of: (a) curriculum development, (b) clinical supervision, (c) staff development, and (d) teacher evaluation" (p. 5).

The work of Jentz and Wofford (1979) focused on administrators and the ways they can become more effective in working with and helping subordinates do a better job using highly skilled interpersonal behaviors.

Researchers have found that principals of achieving schools have certain factors or methods in common in providing strong administration. According to Lipham (1982), successful principals use a situational management style and vary their behaviors as the situation warrants. The single most important factor in determining the success or failure of a school is the ability of the principal to lead the staff in planning, implementing and evaluating improvements in the school's educational program. The contingency theory 
would then seem to be saying that a low task, human relations oriented principal should not be placed in an underachieving school if the student body of that school is expected to achieve.

The literature overwhelmingly suggests that the principal's management style and commitment make a difference in school climate and student achievement. Gretchko and DeMont (1980) found successful principals to have positive self-images and pride in the principalship. For them the principalship was not a way station to the central office but a goal in and of itself. Benjamin (1981) found that principals of achieving schools cared more about the academic progress than human relations.

Manasse (1984) postulated that principals of successful schools, like high performing leaders in the private sector, have a vision of what their schools should be and of their role in achieving it. Manasse suggested that effective principals are proactive, "the effective principal has the skills necessary to bring all the individuals and subsystems into congruence so that they all work toward a common goal" (p. 46) .

Dwyer (1984) found that successful principals were able to find resources "where others saw only problems." The principals' expectations for students were essential aspects of their overall school plan and an influence on the nature of their routine activities (p. 35). 
Austin (1979) concluded that in exceptional schools there were strong administrators, meaning that schools were being run for a purpose rather than running from force of habit. Principals participated strongly in the classroom instructional program, felt they had control over the functioning of their schools, and held high expectations for both teachers and students.

Huff, Lake, and Schaalman (1982) believed that analytical skills were key differentiators in comparing average and high-performing principals.

Amor et al. (1976) and Cohen, Miller, Bredo, and Duckworth (1977) pointed out the importance of the principal's role in maintaining order, acting as an agent of change, setting clear objectives, conveying high expectations for student achievement, offering support and guidance to teachers, providing public rewards and incentives, and spending time in the classroom.

However, ethnographic studies of principals' day-to-day routines have demonstrated that principals do not, in fact, spend substantial amounts of time attending to instructional activities (Glatthorn \& Newberg, 1983; Howell, 1981; Wolcott, 1973).

stronge (1988) suggested that a typical principal performs an enormous number of tasks daily but only $11 \%$ of these tasks are related to instructional leadership. Buffie (1989) agreed with the lack of time spent on instructional leadership and suggested that effective 
leaders are visionary and communicative, and develop high levels of trust and collegiality.

Blumberg and Greenfield pointed to the same problem:

Men and women principals themselves are not clear, as a group, regarding their role priorities. While many seem to aspire to enacting a conception of themselves as instructional leaders, relatively few appear satisfied that they are performing well in this area, and many recognize they lack the skill and knowledge needed to be effective in this domain. (1980, p. 45) Though the principal has an indirect influence on student achievement by becoming an administrator of instruction, it is the teacher who instructs the students. Therefore, it is the teacher who directly influences student achievement. Austin (1979) found that in exceptional schools teaching staffs had greater experience and more pertinent education. "Teachers felt free to try new teaching techniques and expected children to show high achievement and display good citizenship" (pp. 10-12).

Effective teachers increased engagement time or time on task for students. These teachers set learning goals and informed students and parents of them, actively assessed student progress toward achieving the goals, and frequently made class presentations illustrating how to do assigned work. Teachers held high expectations for themselves and students (Bossert, 1971; Brophy, 1979; Fischer, Filby, Marliane, Cahan, Dishaw, Moore, \& Berliner, 1978; Good \& 
Grouws, 1977). Murnane (1981) found that teachers who participated in postgraduate courses were more effective. These teachers appeared to be highly motivated and motivation is critical to teacher effectiveness.

Greenblatt, Copper, and Muth (1984) stated that "teachers do better when their principals follow the ten commandments of consultations" (p. 58). This, in summary, suggests that consultation be taken seriously and used as an effective tool to facilitate the attainment of program goals and expectations.

Thus, it seems that strong, competent leadership and knowledgeable, competent, motivated teachers are needed to effect student achievement. Incorporating the findings of Brookover and Lezotte (1979) and Marcus, Wellish, MacQueen, Duck, and Less (1976), the following nine statements represent a summary of research findings on effective schooling.

1. Achievement gains tend to occur in schools where administrators assume more overall responsibility for policy decisions.

2. Principals who place first priority on decisions concerning the selection of basic instructional materials succeed in raising achievement.

3. Improving goals emphasizes the importance of goal attainment.

4. The staffs of the improving schools tend to believe that all of their students can master the basic objectives 
and, furthermore, the teachers perceive that the principal shares this belief.

5. The staffs of the improving schools hold decidedly higher and apparently increasing levels of expectations with regard to the educational accomplishments of their students.

6. Teachers and principals in improving schools are much more likely to assume responsibility for teaching the basic reading and mathematics skills and are much more committed to doing so.

7. In the improving schools, the principal is more likely to be an instructional manager, more likely to be assertive in his/her instructional management role, is more of a disciplinarian, and assumes responsibility for the evaluation of the achievement of basic objectives.

8. The improving school staffs appear to evidence a greater degree of acceptance of the concept of the individual teacher's accountability and are further along in developing an accountability level.

9. Differences in the levels of parent involvement in the improving and declining schools are not clearcut, suggesting that we need to look more closely at the nature of the involvement exercised by parents.

Reitzug (1989) concluded that the effective leader is visible and interacts with his/her staff as a person and as a professional. He or she shows concern for staff members as employees and as people while expecting much, demanding the best and being supportive and appreciative. 
Sergiovanni (1987) suggested that the key to successful schooling is leadership density. This refers to the utilization of all existing leadership in a school site among such groups as teachers, supervisors, and administrators. The principal's direct leadership remains important, but no less important are the principal's efforts to build, maintain and expand levels of leadership density.

Rost (1991) states, "Leadership is an influence relationship among leaders and followers who intend real changes that reflect their mutual purposes" (p. 102).

The literature overwhelmingly suggests that effective principaling leads to effective schooling and further states that effective schools are further along in accepting and developing an accountability model. It becomes evident that the school principal's role has changed from one of being an effective principal to one of being accountable for being an effective principal.

\section{Accountability}

The idea of educational accountability is not a new one. Wynne (1972) suggested that many attempts to achieve accountability have been made. In October, 1957, Russia launched sputnik, the first man-made satellite. This dramatic event triggered a strong drive for a more rigorous school curriculum. "In addition, within a month of the Sputnik orbit the National Defense Education Act was introduced in Congress. The Act was intended to supply funds to 
further science course and generally improve the quality of high school education" (Wynne, 1972, p. 110).

In the recent past, Project Talent, funded by the Office of Educational Research in 1959, was the first largescale effort in modern school output evaluation in the United states. Project Talent was feasible only with the development of computers as it compared the performance on uniform, objective and traditional tests of a large number of pupils in many schools against the level of expenditures, size of classes, qualifications of teachers, and socioeconomic background of the students in those schools. The objective was to discover which combination of resources worked best with certain students.

Further concern for educational accountability was demonstrated in the 1954 supreme court ruling of Brown v. Board of Education. The court held that deliberate school segregation by race was unconstitutional on the premise that segregated schools had the effect of handicapping black students, even if facilities and expenditures were equal to those of whites. Thus, educational policy was concerned with not only inputs in school dollars but with outputs and effects as well.

In 1965, funds for Title I of the Elementary and Secondary Education Act were appropriated for schools having concentrations of children from low-income families. Utilizing data from Project Talent, researchers demonstrated that children having low levels of school performance needed 
special funding for remedial programs. However, along with federal funding came federal guidelines, regulations and evaluations. Here was another attempt at accountability. In 1963, Pennsylvania began a statewide accountability process articulating ten goals which included cognitive and affective values as well as mastery of the basic skills. School districts gave evidence of accountability efforts in the following ways: in New York City, the United Bronx Parents prepared training materials for parents on school evaluation, including comparisons between interschool reading averages, reading scores, and other pertinent data for 110 elementary schools (Lurie, 1971). The columbus, Ohio accountability system included an annual, school-byschool output report available to all citizens (Cunningham \& Nystrand, 1969; Merriman, 1970).

Performance contracting, too, became an outgrowth of the emphasis on school accountability and the apparent failure of the compensatory education programs designed along traditional lines. Performance contracting proposed that private contractors be paid to teach students with payment partly conditioned on the production of measurable, prespecific results. The first such arrangement between a contractor and a public school occurred in 1969 in the Texarkana School District, and in 1970 the San Diego Unified School District became the first urban district to follow the Texarkana example and work out a performance contract 
with the private firm of Educational Development Laboratory (Lessinger, 1970).

On March 3, 1970, President Nixon articulated the need for educational reform by sending a message on education to Congress. School systems were called upon to "begin responsible, open measurement knowledge of how well the educational process was working" and the concept of accountability was firmly endorsed:

School administrators and school teachers alike are responsible for their performance, and it is in their interest as well as in the interests of their pupils that they be held accountable. . . Ironic though it is, the avoidance of accountability is the single most serious threat to a continued and even more pluralistic educational system. (Nixon, 1970, p. 304) The 1970 call for reform was evidently not expedient, as the call for accountability continued to echo. Alkin (1972) suggested that the public had lost faith in educational institutions. Traditional acceptance of educational programs on the basis of their past performance was no longer the rule. Instead the public now demanded that schools demonstrate that resources were being utilized properly. According to Vincent (1984), California's Proposition 13 severely limited the ability of school districts to be accountable. While the tax referendum was not a revolt against taxes per se but against the equity or distribution of the property tax, the approval of this 
proposition shifted the burden of school financing away from the property tax and to the state government. Local school districts lost local control and the cutbacks weakened district programs.

The need for educational reform continued to be of national priority evidenced by the creation of the National Commission on Excellence in Education in 1981. In April of 1983, the commission transmitted the report entitled $\underline{A}$ Nation at Risk: The Imperative for Educational Reform. The findings of the commission were shocking, stating that "had an unfriendly foreign power attempted to impose the existing level of educational mediocrity, that we as a nation might have viewed the imposition as an act of war" (National Commission, 1983, p. 5) . Recommendations were made. Schools, colleges, and universities must adopt more rigorous, measurable standards and higher expectations for academic performance and student conduct.

In response to these recommendations, the passage of Senate Bill 813 marked the beginning of a major reform in the public schools of California. The bill established a systematic accountability effort to implement short- and long-term educational reforms to improve the quality of education. In general, the total reform package of senate Bill 813 included: (a) strengthening the graduation requirements and improving instruction, (b) attracting and retaining the highest quality teachers and administrators, (c) improving school personnel management practices, 
(d) enriching school programs and educational options,

(e) improving the efficiency and coverage of categorical programs, (f) strengthening school authority over student discipline, and ( $g$ ) making effective use of school facilities.

The California Commission on the Teaching Profession released its who will Teach our children report, also known as the "Commons Report," in 1985, which included within its thirteen recommendations: (a) the need to restructure the teaching career and to establish rigorous professional standards while establishing a new system of setting and enforcing professional standards; (b) the need to redesign the school as a more productive workplace for teachers and students; and (c) the need to restructure the management of California schools. While many of the commission's suggestions related to teacher improvement, as well as the improvement of the educational process as a whole, there were also recommendations which would impact site administrators as they were to move toward a more participatory management style and the implementation of recommendations for which they were responsible.

In 1985, Becoming a Nation of Readers gave further recommendations for the improvement of reading in all children which were to assist them to attain levels of literacy far beyond the basic competencies. Tomorrow's Teachers, also known as the "Carnegie Report," released in 1986, made hard hitting recommendations for teacher 
educational training reform, among them the need for the career professional teacher, administrators were to insure mutual exchange between research and practice to provide teachers with opportunities to contribute to the development of knowledge in their profession.

A Nation Prepared: Teachers for the Twenty-first Century in some instances reiterated and restated many of the recommendations found in Tomorrow's Teachers and also suggested that a new category of lead teachers with the proven ability to provide active leadership be implemented along with teacher incentives related to schoolwide performance.

Educational reform as seen through all of the aforementioned studies calls for more stringent preparation and expectations for teacher training and credentialing, while strongly suggesting that there is a need for greater teacher and parental involvement within site decision making.

Without question, the administrator's responsibility for the proper implementation of the instructional program makes him/her also responsible for teacher effectiveness, for the administrator through the evaluation process and provision of technical assistance insures that the individual needs of students are being met.

Abbott (1988), superintendent of Mt. Diablo Unified School District and member of Deukmejian's Commission on Educational Quality, articulated, "Governor Deukmejian stated that the public has a right to expect results from 
public schools. The problem," he said, "is that American education is too often unproductive, overregulated and underaccountable" (p. 8). State superintendent Bill Honig has set accountability and staff development as top priorities for the state of California.

Abbott stated that every school district should have in place a clearly defined annual plan which includes:

1. Specific outcomes to be accomplished.

2. Expected levels of achievement.

3. A process for gathering and communicating data.

4. Clearly defined areas of responsibility.

5. Specific processes for monitoring progress.

6. Specific processes to ensure that all district resources are directed at accomplishing the outcomes.

7. Incentives for successful schools.

8. Intervention for schools that fail to achieve their goals within a reasonable period of time.

9. Communication of expectations and results to the Board of Education and community.

In this plan, Abbott referred to superintendent accountability and responsibility. Further examination of this plan shows its adaptability to site administration. specifically, the outcomes are derived from four sources:

1. Quality indicators from the state.

2. Specific objectives established for all schools by the superintendent and the Board of Education. 
3. Specific objectives established by the assistant superintendent to address problems identified at a particular school site.

4. Specific objectives established by the school staff and/or school site council.

He recommended district intervention for schools that are unsuccessful in meeting their objectives for two consecutive years. A team of principals and teachers from successful schools along with district administrators, curriculum and staff development personnel assists the school in the analysis and development of an action plan. The school is then given three years to successfully implement the district's action plan. If still unsuccessful, Abbott recommends state intervention (pp. 8-10).

Reeves (1988) suggested that since the report of the National Commission on Excellence in Education issued $\underline{A}$ Nation at Risk five years ago, virtually every state has acted to impose its recommended higher standards; however, an implicit message has been ignored. Before we can truly reach rigorous standards, we must first address the needs of our weakest students to ensure their success. In comparing our educational system to that of the Japanese, she stated that the Japanese achieve their extremely high average level of academic performance by taking care that their weakest students do well. As they have often claimed, they have "the best bottom $50 \%$ in the world" educationally, and they have virtually no dropouts. 
Melendez (1991) stated that, "Administrators must acknowledge that current educational strategies may not work for a growing number of minority students, and start designing ways to ensure that these students can succeed in school" (pp. 8-10).

Gross and Furey (1987) posit that today's principal is like the director of a play, charged with taking a script written by a talented playwright and making it come to life on his or her own stage. Though the principal may not be enamored with the script, clearly different skills are required to meet this challenge. If principals are to be accountable, increased training should be provided in the areas of monitoring, implementation of curriculum and the interpretation of test data. In addition, added supports are needed for principals in the training of staff in implementing new instructional systems.

Burns and Lindner (1985) alluded to the need for the states as policy makers to move quickly in assessing and documenting educational excellence, as failure could potentiaily be catastrophic for public education. considered is the fact that many states have enacted changes in teacher certification, compensation and recruitment while designing ways to increase the quality of teachers in the classrooms. Examples of evaluative techniques are suggested.

Peters and Waterman (1982) found that highly motivating teaching conditions were present when teachers found their work lives meaningful, had reasonable control over their 
work activities and experienced personal responsibility and accountability for outcomes. Again, this seems to suggest a more global view of shared accountability.

Snider (1989) stated that the Hawkins-stafford Act of 1988 marked the first time that effective school principals were included in a federal law. It provided for explicit options which districts could fund with Chapter 1 or Chapter 2 aid and contained specific provisions for school accountability. In general, the Educational and Labor committee found that much of the research on effective schools was based on schools where teachers and principals attempted to raise the academic performance of students through a bottom up process. The committee focus, however, was on how research could be applied through a top down process from district central offices or county offices which, again, suggests accountability and perhaps a greater resurgence toward state conducted school program quality reviews.

Olson (1991) concluded that proposals to provide parents with a choice among public and private schools are reviving and surfacing at all levels of government and being fueled by President Bush's $\$ 200$ million-dollar plan to reward districts that develop choice policies which enable parents to enroll their children in public or private schools.

Governor Thompson of Wisconsin has endorsed the hiring of private practice teachers for public schools and outlined proposals to: 
1. Permit schools to obtain waivers from state regulations that hindered their ability to try innovative education programs;

2. Give bonus grants for schools that show improvement;

3. Create a panel to set education goals for the state and develop and oversee a system to measure schools' progress in meeting those goals;

4. Issue report cards on every school and mandate achievement testing for all students in grades $3,5,7,9$, and 10;

5. Allow high-school juniors and seniors to take courses for free at any state postsecondary school; and 6. Transform auditors for the state education department into school-improvement teams aiding "Iow performing" school districts (Thompson, 1991, p. 18).

Proposition 98 passed in California in 1988 requires that boards issue an annual school Accountability Report Card on each school which addresses information on thirteen school conditions suggested by the state which includes:

1. Student academic progress and CAP test data.

2. Dropout prevention progress or strategies.

3. School description and funding sources.

4. Class size.

5. Adequacy of teacher and administrator evaluation.

6. School climate/discipline.

7. Curriculum improvement. 
8. Quality of school instruction and leadership.

9. Comparison of salaries for teachers, administrators and superintendents as well as the percentage of budget allocated for teacher and administrative personnel against statewide averages (Brown, 1990, pp. 1-6).

Bratlie (1987) and Hunt (1989) discussed the importance of principal influence as a change agent in the implementation of school-based decision making and teacher autonomy. The principal, however, remains the accountable person for student outcomes as shared accountability is not adequately addressed.

Zurhellen (1987) suggested that accountability as currently practiced shows little evidence of having produced better teachers or instruction and attributed this result to the manner in which accountability is viewed as a one-way flow of responsibility which is contrary to our democratic sense of fairness. Zurhellen believes that a two-way relationship among all participants that recognizes both controllable and noncontrollable inputs is essential to accountability systems. Benveniste (1984) postulated that accountability implies external control in which output accountability is emphasized. We must begin to emphasize accountability input, which means that there is a need to reexamine teacher and administrator training and to jointly design restructuring systems around measures which provide direct information to teachers, parents and administrators on how to rectify their behavior to facilitate desired 
outcomes. Additionally, Benveniste indicated that there is good and bad accountability. Good accountability serves to positively reorient action and measures what is important. Bad accountability is costly, takes too much time away from teaching or, in the case of the administrator, instructional leadership duties, and is difficult to measure.

\section{Summary}

We can see from the Reeves and Abbott statements that though pressure is being placed on principals, the movement is linear and moves from top to bottom, from the state to the local school district to the school site. With communication and information moving in this downward mode, one wonders how much pertinent information regarding accountability implementation as it concerns district needs and constraints filters upward. Above all, the movement cannot be considered a whim. Instead, it should be viewed as an ever evolving and necessary part of the educational system. We also are made aware of the rebirth of the voucher (choice) system and the many hats that site principals wear, from setting up site governance schoolbased decision making teams to creating a safe and orderly environment, often in the midst of turmoil such as the Cleveland Elementary school yard shooting spree that took place in stockton, California, documented by Jennings (1989, p. 1). 
CHAPTER III

RESEARCH DESIGN AND METHODOLOGY

\section{Introduction}

The three objectives of this study are to ascertain the impact of the educational accountability movement on selected principals in the San Diego Unified School District from 1983 to 1986, the changes accountability has had on the role of the principal, and the identification from the principal's perspective of the skills and knowledge necessary for today's instructional administrators. Survey research and qualitative methods have been used to obtain the necessary data. The data gathered from the survey were analyzed to determine the (a) specific areas of school site accountability which had the greatest impact on the school administrators, (b) problems or stressors encountered in the creation or maintenance of an effective school, (c) delineation of characteristics and knowledge needed for the successful principal, and (d) recommended consequences for educators who are unable to achieve student learning results that had been agreed upon under the accountability program. Findings of this study provide the basis for recommendations for greater school site support and will facilitate an understanding of the accountability movement within the 
district under study for prospective and current administrators.

\section{Research Methodology}

The methodology for this research includes the use of survey questionnaire data and was chosen by the researcher because it facilitates broad based data collection which, in turn, gave greater insight into the study in question and into the beliefs and feelings of survey respondents. Babbie (1973) described survey research as a study of a segment or portion of a population for the distinct purpose of making estimated assentations or characterizations about the nature of the total population from which the sample has been selected.

Educational researchers have long accepted the use of survey research methods. Witkins (1984) and Borg and Gall (1983) have observed that surveys are the most widely used procedures in educational studies.

\section{Data Gathering}

\section{Survey Instrument}

A four-page instrument designed to gather the data needed for this study consisted of a demographic data sheet and 24 questions (Appendix A). Approximately 19 of the 24 questions were constructed to allow a fine choice response similar to that of the Likert scale. The remaining questions were constructed to elicit an open-ended written response. The survey consisted of 19 questions which 
utilized the closed-question format. A numerical Likertlike rating scale with a range from 1 (strongly agree) to 5 (strongly disagree) was used. Questions were organized in five clusters.

Cluster 1. To what extent should the following people be held responsible for making the education process functional? These questions asked for individual ratings on teachers, principals and central office staff.

Cluster 2. To what extent has the impact of the accountability movement affected you as a principal? These questions focused on organizational expectations and pressure to perform, being accountable for student achievement (test scores) and becoming an instructional leader.

cluster 3. What has caused the accountability movement in the district under study? These questions focused on the principal's opinions as to the cause of the accountability movement and looked at parent-school communication; the lack of qualified, committed teachers and administrators; the actions of the school board and central office administrators; and the policies of the state superintendent of Education, Bill Honig.

Cluster 4. What problems have been encountered in creating or maintaining an effective school? These questions focused on the lack of central office support, time constraints and teacher observations, uncooperative teachers or teachers in need of technical assistance and lack of parent participation. 
Cluster 5. How should site administrative results be defined and measured: Through the use of the administrators' evaluation form, student standardized tests, California Assessment Program or Program Quality Review?

During the construction of this survey, this researcher realized that using the open-ended question format would take respondents more time to complete than closed questions; however, these open-ended questions allowed respondents to make distinctions that are seldom possible with closed question formats. Further, an open-ended format gives respondents the opportunity "to express themselves in a language that is comfortable for them and congenial to their views" (Sudman \& Bradburn, 1982, p. 50). In order that research objectives be met, it was essential that respondents be given the opportunity to express their opinions related to the experiences they had at the schools without being guided into a particular response. Schuman and Presser (1981) suggested that "respondents are apt to be influenced by the specific closed question alternatives given, and therefore a more valid picture of respondent choice is obtained if they must produce an answer themselves" (p. 81).

In analyzing the administrators' responses to the five open-ended questions, this researcher used a procedure which provided ample space for the response to be transcribed and then compared the answers for similarities. 
The demographic portion of the survey (Appendix A) required respondents to indicate data that describe their gender, school, level, number of years as site principal, the number of teachers assigned to their sites, and number and type of categorical programs on each site.

The validity of the survey questions was developed in preliminary tests of the survey questionnaires and followed up by a small pilot study. The preliminary testing of the questionnaire included four administrators who were asked to review the proposed questions for the following:

1. Clarity of instructions

2. Suggested additions or deletions

3. Relevance to the topic under study

4. Questionnaire format--leading questions

5. Ambiguity in wording

6. Length of the questionnaire.

The suggestions made by the administrators were incorporated into the revision of the questionnaire and became the first step in securing feedback concerning the content validity of the proposed questionnaire. The actual pilot study of the questionnaire took place in early spring of 1987 to determine content validity. A small sampling of principals from elementary and secondary schools was chosen on the basis of a systematic random sampling. The survey questionnaire was mailed to the pilot sample with a letter of transmittal (Appendix B). They were asked to fill out the questionnaire while adhering to the directions. When 
the questionnaires were returned, they contained answers that showed that the questionnaire and the wording of the questions were clear and that content validity was obtained. In May, 1987, a survey mailing list was constructed by systematically selecting every third elementary school and every second secondary school. Secondary schools encompassed grades 7-12 and were junior high, middle schools and senior high schools. The survey instrument (Appendix A) along with a one-page, signed letter of transmittal from the researcher (Appendix C) was sent to 50 school administrators $\mathrm{K}-12$.

Borg and Gall (1979), Backstrom and Hursh (1963) and Babbie (1973) have delineated items which all letters of transmittal should contain. Thus, the letter contained the following information:

1. Purpose of the study.

2. Reasons for data collection.

3. The importance of the study.

4. The date the questionnaire had to be returned.

5. How long questionnaire would take to complete.

6. Results availability.

The first mailing of survey questionnaires took place in mid-May, 1987, with a return date of May 30. A coding system which had been put in place during the sampling procedure allowed the researcher to actively track questionnaire returns and to determine the number of follow-up mailings to be made. 
The 50 schools in this sample represent approximately one-third of the schools in the district. since the researcher had been sanctioned by the district under study, the researcher was allowed to use the school mail system for questionnaire delivery and return.

A response rate of $80 \%$ was attained. As such, the number of school administrators responding to the questionnaire is of sufficient size to draw conclusions that are generalizable to the larger population of other large urban school districts. Babbie (1973) stated that "a response rate of at least 50 percent is adequate for analysis and reporting. A response of at least 60 percent is good. And a response rate of 70 percent or more is very good" (p. 165)

Backstrom and Hursh (1963) indicated that:

The purpose of survey research is to estimate characteristics of a population . . sampling implies some discrepancy between the actual and the estimated value of a characteristic. . . The discrepancy between the sample estimate and the number value that would have been found under identical conditions by a census of all respondents is the sampling error. The sampling error for which we must allow, affects the reliability of the sample estimate. (p. 28)

The inclusion by this researcher of 50 schools reduces the percentage of sample error and increases the accuracy of any generalizations made about the total population. 
The researcher also collected qualitative data through holding 40- to 60-minute interview sessions with six principals: two from elementary, two from junior high and two from senior high schools. Schools were selected primarily based on the school administrator's calendar, flexibility and willingness to participate in the study. Based on these criteria, two elementary schools were selected: one with multiple external funding programs such as Chapter 1, Achievement Goals Program, and programs addressing the needs of Limited English Proficient Students; and the other, a school with minimal external funding programs.

Most secondary schools within the district under study have only limited external funding programs such as the School Improvement Program. Thus two junior high and two senior high schools with limited programs were selected for this study. During the selection of the six schools, geographical location, school size and principal gender were also taken into consideration.

Principals at these sites were interviewed using 16 interview questions (Appendix D). Interview questions were written to elicit some of the same information derived from survey questionnaires with two major differences, but all of the questions were open-ended and required verbal responses that delved deeper into the administrator's justification for some of the answers given. Also interviewed were key central office personnel: the superintendent of schools, 
one school board member and three assistant superintendents. The purpose of these interviews was to ascertain in greater depth the impact of the accountability movement from the perspective of central office personnel.

\section{Data Analysis}

\section{Survey Questionnaire}

After the questionnaires were returned, the personal information related to demographics, gender, ethnicity, and years of administration were assigned numerical values, i. e., male (1) and female (2), for consistency and ease of tally. These coding procedures were also utilized in determining ethnicity of respondents as questionnaires were coded to reveal this information before their mailing. In analyzing the quantitative data, categories based on assigned numerical values were developed to facilitate cross category comparisons of male to female responses, and comparisons of responses between ethnic groups to ascertain significant differences in perception and to provide the researcher with a richer insight into impact of the accountability movement from several different perspectives. This researcher also looked at school demographics to find out if the location of the school within the district would evidence significant differences in principal perceptions related to the impact of the accountability movement, i. e., principals of schools in affluent areas compared to those in low socioeconomic areas. Overall, frequency distributions 
were used to analyze the data and scaled responses were analyzed with summaries of dispersion that reported the mean and mode through the use of computer. These data were then illustrated in a meaningful display of charts and tables. In analyzing the data provided by the open-ended questions on the questionnaire, the researcher looked for similar responses. Like responses were grouped together and frequencies determined.

Only two respondents left blank spaces. The researcher did not consider them significant enough to affect the survey with a sampling bias.

\section{Interviews}

The researcher transcribed verbatim, by hand, everything said by interviewees. Those interviewed did not feel comfortable having their interviews on tape.

An analysis was made of each of the sixteen interview questions again, looking for likeness in responses and personal or individual perceptions and beliefs which may have been significantly different from the norm. Realizing that several principals had hastily retired or were planning retirement, the unspoken question in the back of this researcher's mind was, would the interviews uncover unhappiness and apprehension with the new expectations brought on by the accountability movement? Therefore, data were carefully analyzed looking for responses that might answer this question through inference that was not on the 
questionnaire, but nonetheless important. Also analyzed were likenesses and differences in perceptions of central office staff compared to school principals.

\section{Limitations of study}

This research had one limitation. The archival records did not yield the copious background information that the researcher had expected to glean. Much of the background had been handed down by word of mouth, but had not been placed in written policy or procedure.

\section{Summary}

The researcher utilized the survey method to elicit information from k-12 school administrators about their feelings on the effective schools/accountability movement as it affects the principalship. The survey questionnaire included open-ended and closed questions which allowed participants to express their personal views and opinions. Also utilized were the qualitative methods of personal interview. Much of the survey analysis was done using a statistical computer program, while the qualitative data required hand transcriptions. 
CHAPTER IV

\section{ANALYSIS OF EDUCATIONAL ACCOUNTABILITY MOVEMENT DATA}

The purpose of this research is to ascertain the impact of the educational accountability movement on the behavior of selected principals in the school district under study from 1983 to 1986 , and to determine what changes this movement has had on the role of principals, while identifying from the principal's perspective the areas of skill and knowledge necessary for today's principals as instructional leaders. An analysis of the similarities and differences among the respondents from elementary, middle/ junior high and secondary schools is included in this study. The data are presented in a meaningful display of charts and tables. Raw scores are shown only where appropriate and where they add descriptive explanation to the analysis. With regard to the responses to the open-ended questions on the questionnaire, all responses were abbreviated, similar responses were grouped together and frequencies determined. The survey was divided into nine basic sections; each section posed a question and dealt with a specific subject as listed in Table 1. 
Table 1

Survey Questions and Subject Areas

Section Questions Subject area

\begin{tabular}{lcl}
\hline 1 & $1-3$ & Responsibility \\
2 & $4-6$ & Accountability \\
3 & $7-11$ & Cause of the movement \\
4 & $12-16$ & Problems encountered \\
5 & $17-20$ & Measurement of results \\
6 & $21^{\mathrm{a}}$ & Characteristics/instructional leaders \\
7 & $22^{\mathrm{a}}$ & Knowledge for today's principal \\
8 & $23^{\mathrm{a}}$ & Consequences \\
9 & $24^{\mathrm{a}}$ & What must be changed \\
\hline
\end{tabular}

apen-ended questions.

\section{Demographic Analysis of the Respondents}

The school administrators were selected by a systematic random sample of elementary and secondary administrators in the district under study during the 1986-87 academic year. Forty administrators responded by completing the questionnaire. These responses were organized into the geographical locales of north, south, east, west and midcity as well as Areas I, II, III and IV, because the district under study is decentralized into four areas, with one assistant superintendent heading each area. Table 2 shows the geographical distribution of the respondents. 
Table 2

Geographical Locales of the Respondents

\begin{tabular}{|c|c|c|c|c|c|}
\hline \multirow[b]{2}{*}{ Locales } & \multirow{2}{*}{$\begin{array}{l}\text { Number of schools } \\
\text { represented }\end{array}$} & \multicolumn{4}{|c|}{ Area } \\
\hline & & $I$ & II & III & IV \\
\hline North and northwest & 7 & - & - & 3 & 4 \\
\hline South & 8 & 4 & 1 & 1 & 2 \\
\hline East and southeast & 14 & 1 & 7 & 4 & 2 \\
\hline West & 6 & 4 & 1 & - & 1 \\
\hline Mid-city & 5 & 1 & - & 1 & 3 \\
\hline Total & 40 & & 9 & 9 & 2 \\
\hline
\end{tabular}

The survey asked the administrators to indicate the categorical programs at the school. Categorical programs are state and federally funded programs which for this study encompass the following:

AGP: Âchievement Goals Program is a district developed program designed to improve student basic skills acquisition.

ABC: Âlready Balanced Ćomunity schools are schools with a natural residential ethnic balance.

Bilingual: These programs assist limited English proficient students by providing instruction in their primary native language when possible and assistance in the learning of English as a second language. 
Chapter I: The first chapter of the Education Consolidation and Improvement Act addresses the special educational needs of low-achieving students affected by language, cultural, and/or economic disadvantages.

Chapter II: The second chapter sets up a Basic skills Assistance Supplementary Program (BSASP), which is funded by both the district and federal government. The program is aimed at improving the basic skills of students.

Gifted and Talented: The GATE program is accessed through testing, certification, or teacher recommendation. GATE students receive 200 minutes of qualitatively different and challenging instruction per week.

Magnet: The Magnet Program is a voluntary integration program. Magnet schools offer programs with specialized emphasis in areas such as drama, dance, athletics, and space exploration along with the academic emphasis.

School Improvement Program: SIP is designed to improve education at all levels, $\mathrm{K}-12$, has a parent involvement component, and requires periodic program reviews for continued funding.

Special Education: These programs provide for all special need children, including the handicapped. An individually planned instructional program is designed to respond to the unique characteristics of children whose needs cannot be met by the standard school curriculum. 
Voluntary Ethnic Enrollment Program: A program that allows voluntary bussing across residential community areas for ethnic and racial balance.

The information in Table 3 provides some insight into the number of site programs that respondents monitored in their schools. The more programs a site has, the greater the impact on the school and site administrator. In addition, information can be gleaned about which programs are most common and some inference can be made about site needs. Table 3 shows program distribution among the 26 elementary, 8 middle/junior high, and 6 secondary high school respondents.

Each administrator was asked to indicate the number of years that he or she had been a principal and the number of teachers supervised. Nineteen (47.5\%) of the respondents indicated that they had been head of a school between 0-5 years, and 6 (15\%) had been administrators for between 6 and 10 years. The remaining 15 (37.5\%) respondents had been school administrators for longer than 10 years.

The number of teachers supervised by these administrators ranged from 0-12 to 66 or more. Five percent (2) of the respondents supervised 0-12 teachers, 45\% (18) supervised 13-24 teachers, 17.5\% (7) supervised 25-40 teachers and $15 \%$ (6) were responsible for $41-65$ teachers, while $17.5 \%$ (7) had 66+ teachers on site. 
Table 3

Categorical Programs at the 40 Schools

\begin{tabular}{|c|c|c|c|c|}
\hline \multirow[b]{2}{*}{ site programs } & \multicolumn{3}{|c|}{ Number of schools } & \multirow{2}{*}{$\begin{array}{c}\text { Percentage of } \\
\text { schools with programs }\end{array}$} \\
\hline & Elementary & Middle/Junior & Senior & \\
\hline Achievement Goals Program & 3 & 1 & - & 10 \\
\hline Already Balanced Communities & 3 & 1 & 1 & 13 \\
\hline Bilingual & 9 & 3 & 2 & 35 \\
\hline Chapter I & 11 & 2 & 2 & 38 \\
\hline Chapter II & 14 & 4 & 3 & 53 \\
\hline Gifted \& talented & 10 & 3 & 1 & 35 \\
\hline Magnet & 5 & 2 & 2 & 23 \\
\hline School improvement & 24 & 6 & 2 & 80 \\
\hline Special education & 10 & 2 & 1 & 33 \\
\hline Voluntary Ethnic Enrollment & 10 & 4 & 3 & 43 \\
\hline
\end{tabular}


of the 40 respondents, 20 (50\%) were male while the remaining 20 (50\%) of the respondents were female. The ethnicity of respondents is shown in Table 4.

Table 4

Ethnicity of the Respondents

\begin{tabular}{lcccc}
\hline Value & Frequency & Percent & $\begin{array}{c}\text { Valid } \\
\text { percent }\end{array}$ & $\begin{array}{c}\text { Cumulative } \\
\text { percent }\end{array}$ \\
\hline Black & 6 & 15.0 & 15.0 & 15.0 \\
White & 25 & 62.5 & 62.5 & 77.5 \\
Hispanic & 7 & 17.5 & 17.5 & 95.0 \\
$\begin{array}{l}\text { Asian and } \\
\text { Pacific Islanders }\end{array}$ & 2 & 5.0 & 5.0 & 100.0 \\
\hline
\end{tabular}

The information in Table 4 provides the ethnic breakdown of respondents and provides insight into the possible overall makeup of administrators in the district.

\section{Analysis of the study}

Impact of Accountability on Principal Behavior

The first objective of this study is to ascertain what impact the educational accountability movement has had on the behavior of selected principals in the district from 1983-86. The respondents were asked to what extent the accountability movement had affected them as school principals. 
The information in Table 5 shows that nearly $87 \%$ of the respondents showed strong agreement or general agreement that they have felt the impact of the accountability movement through higher district organizational expectations and site pressure to perform. Thus, from the school principals' perspective, the accountability movement was not only alive and well, but appears to be causing a state of change in the district under study. This change is affecting principal behavior. The status quo seems no longer the acceptable mode of doing business.

Table 5

Higher Organizational Expectations and Pressure to Perform

\begin{tabular}{|c|c|c|c|c|}
\hline Value & Frequency & Percent & $\begin{array}{l}\text { Valid } \\
\text { percent }\end{array}$ & $\begin{array}{c}\text { Cumulative } \\
\text { percent }\end{array}$ \\
\hline Strongly agree & 20 & 50.0 & 51.3 & 51.3 \\
\hline Agree & 3 & $22 \cdot 5$ & 23.1 & 74.4 \\
\hline Somewhat agree & 5 & 12.5 & 12.8 & 87.2 \\
\hline Disagree & 3 & 7.5 & 7.7 & 94.3 \\
\hline strongly disagree & 2 & 5.0 & 5.1 & 100.0 \\
\hline No answer & 1 & 2.5 & & \\
\hline Total & 40 & 100.0 & 100.0 & \\
\hline
\end{tabular}


In Table 6 accountability for student achievement is a pressure that was being significantly felt by the majority of the respondents who believed that the effective schools movement was manifesting itself through principal accountability for student achievement test scores (i. e., California Test of Basic skills [CTBS] and California Assessment Program [CAP]).

Table 6

Accountability for Student Achievement

\begin{tabular}{lcccc}
\hline Value & Frequency & Percent & $\begin{array}{c}\text { Valid } \\
\text { percent }\end{array}$ & $\begin{array}{c}\text { Cumulative } \\
\text { percent }\end{array}$ \\
\hline Strongly agree & 21 & 52.5 & 52.5 & 52.5 \\
Agree & 11 & 27.5 & 27.5 & 80.0 \\
Somewhat agree & 5 & 12.5 & 12.5 & 92.5 \\
Disagree & 2 & 5.0 & 5.0 & 97.5 \\
Strongly disagree & 1 & 2.5 & 2.5 & 100.0 \\
\hline
\end{tabular}

An analysis of variance was completed between male and female administrators to see if the impact of the accountability movement was affecting them differently. Female administrators as a group strongly agreed that they had been impacted by the accountability movement, while the male administrators as a group only agreed that they had been impacted (Table 7 ). The difference was significant at the .05 level. 
Table 7

To What Extent Has the Impact of the Accountability Movement Affected You as a Principal Becoming an Instructional Leader

\begin{tabular}{lcccc}
$\begin{array}{l}\text { Sex } \\
\text { of the principals }\end{array}$ & Mean & SD & F value & significance \\
\hline $\begin{array}{l}\text { Female } \\
\text { Male }\end{array}$ & 1.45 & 0.60 & 4.49 & .0408 \\
\hline
\end{tabular}

The researcher analyzed the responses from elementary, junior high and high school principals and sought out areas in which these groups might have responded differently due to grade level school structures. However, no significant differences emerged, that is, elementary principals did not as a group answer survey questions any differently than their secondary counterparts.

Table 8 overwhelmingly suggests that the ability to provide instructional leadership is an extremely important attribute for site administrators. The majority of the respondents indicated that they have felt pressure to be the instructional leader for their school sites.

In summary, the move toward accountable, effective schools has had a significant impact on the behavior of principals through higher organizational expectations which is accompanied by greater levels of stress and pressure to perform. 
Table 8

Pressure to Become an Instructional Leader

\begin{tabular}{lcccc}
\hline Value & Frequency & Percent & $\begin{array}{c}\text { Valid } \\
\text { percent }\end{array}$ & $\begin{array}{c}\text { cumulative } \\
\text { percent }\end{array}$ \\
\hline Strongly agree & 21 & 52.5 & 52.5 & 52.5 \\
Agree & 12 & 30.0 & 30.0 & 82.5 \\
Somewhat agree & 2 & 5.0 & 5.0 & 87.5 \\
Disagree & 4 & 10.0 & 10.0 & 97.5 \\
Strongly disagree & 1 & 2.5 & 2.5 & 100.0 \\
\hline \multicolumn{1}{c}{ Total } & 40 & 100.0 & 100.0 & \\
\hline
\end{tabular}

Student achievement has become one of the greater focal points and also an area of major concern for site administrators as the state of California continues to monitor and apply quality indicators which play an important part in achieving excellence in our schools. Also, the achievement of the students on the California Assessment Program (CAP) tests has been closely monitored as school staffs struggle to fare well within their comparison bands. Thus, there is now a greater need and expectation that principals be instructional leaders.

The Changing Role of the Principal

The second objective of this research is to determine what changes the accountability movement has had on the role of principal. The respondents suggest that they are more 
aware of the need to not only proactively keep current on educational research but of the expectations concerning research and site program restructuring geared to student achievement. This change is different from the past in that most total restructuring efforts have been implemented at the district level. Now, however, the site administrator must be an innovator and, through his or her leadership, prepare the site to play a greater role in totally revamping curriculum/school programs to better meet the needs of children. In addition, the movement has given parents and community members a greater voice in the implementation of school programs and how selected school budgets are to be used. Therefore, there is greater pressure for principals to be extremely visible and active in community activities.

The needs of the school mirror the needs of society. In meeting these needs, the roles of the teacher and of the principal have changed. According to the respondents, their role has greatly expanded in the areas of child protective services and parenting because there is a need to meet as many hygiene factors as possible if children are to be ready to learn.

In Tables 9-12 respondents were asked what problems they encountered in creating and maintaining an effective school. The areas of concern were central office support and funding (Table 9), the time needed for teacher observation and clinical teaching (Table 10), uncooperative teachers or teachers needing technical assistance (Table 
11), and lack of parent participation (Table 12). Of the four areas, lack of central office support and funding and lack of parent participation appeared to be significant problems encountered by the respondents in creating and maintaining effective schools. Surprisingly, the other areas in question shown in Tables 10 and 11 did not seem to cause the problems the researcher anticipated. These findings are significant because they will alert central office administrators to the needs of site administrators which may, in turn, assist in the achievement of a mutual goal, the creation and maintenance of schools which meet the needs of our clientele.

Table 9

The Problems Encountered in creating and Maintaining an Effective School: Lack of Central office support and Funding

\begin{tabular}{lcccc}
\hline Value & Frequency & Percent & $\begin{array}{c}\text { Valid } \\
\text { percent }\end{array}$ & $\begin{array}{c}\text { cumulative } \\
\text { percent }\end{array}$ \\
\hline Strongly agree & 10 & 25.0 & 25.6 & 25.6 \\
Agree & 10 & 25.0 & 25.6 & 51.3 \\
Somewhat agree & 8 & 20.0 & 20.0 & 71.8 \\
Disagree & 8 & 20.0 & 20.6 & 92.3 \\
Strongly disagree & 3 & 7.5 & 7.7 & 100.0 \\
& 1 & 2.5 & & \\
\hline \multicolumn{1}{c}{ Total } & 40 & 100.0 & 100.0 & \\
\hline
\end{tabular}


Table 10

The Problems Encountered in Creating and Maintaining an Effective School: Teacher observation/Clinical Teaching Too Time consuming

\begin{tabular}{|c|c|c|c|c|}
\hline Value & Frequency & Percent & $\begin{array}{l}\text { Valid } \\
\text { percent }\end{array}$ & $\begin{array}{c}\text { Cumulative } \\
\text { percent }\end{array}$ \\
\hline strongly agree & 6 & 15.0 & 15.0 & 15.0 \\
\hline Agree & 9 & 22.5 & 22.5 & 37.5 \\
\hline Somewhat agree & 8 & 20.0 & 20.0 & 57.5 \\
\hline Disagree & 13 & 32.5 & 32.5 & 90.0 \\
\hline Strongly disagree & 4 & 10.0 & 10.1 & 100.0 \\
\hline Total & 40 & 100.0 & 100.0 & \\
\hline
\end{tabular}

Table 11

The Problems Encountered in Creating and Maintaining an Effective School: Uncooperative Teachers or Teachers Needing Technical Assistance

\begin{tabular}{|c|c|c|c|c|}
\hline Value & Frequency & Percent & $\begin{array}{l}\text { Valid } \\
\text { percent }\end{array}$ & $\begin{array}{c}\text { Cumulative } \\
\text { percent }\end{array}$ \\
\hline strongly agree & 3 & 7.5 & 7.5 & 7.5 \\
\hline Agree & 8 & 20.0 & 20.0 & 27.5 \\
\hline Somewhat agree & 9 & 22.6 & 22.5 & 50.0 \\
\hline Disagree & 14 & 35.0 & 35.0 & 85.0 \\
\hline strongly disagree & 6 & 15.0 & 15.0 & 100.0 \\
\hline Total & 40 & 100.0 & 100.0 & \\
\hline
\end{tabular}


Table 12

The Problems Encountered in creating and Maintaining an

Effective School: Lack of Parent Participation

\begin{tabular}{lcccc}
\hline Value & Frequency & Percent & $\begin{array}{c}\text { Valid } \\
\text { percent }\end{array}$ & $\begin{array}{c}\text { Cumulative } \\
\text { percent }\end{array}$ \\
\hline Strongly agree & 3 & 12.5 & 12.5 & 12.5 \\
Agree & 8 & 25.0 & 25.0 & 37.6 \\
Somewhat agree & 9 & 27.5 & 27.5 & 65.0 \\
Disagree & 14 & 25.0 & 25.0 & 90.0 \\
Strongly disagree & 6 & 10.0 & 10.0 & 100.0 \\
\hline \multicolumn{1}{c}{ Total } & 40 & 100.0 & 100.0 & \\
\hline
\end{tabular}

In Tables 13-16 respondents were asked how administrative results should be measured. The areas of concern were administrator success measured by administrator evaluation form (Table 13), measured by student achievement on CTBS (Table 14), success defined by CAP test scores (Table 15), and success to be measured by program quality review outcomes (Table 16).

In defining the criteria to be used in measuring or determining the school and administration's results or success, a great majority of the respondents seemed comfortable with administrative evaluation forms even though these procedures are ever evolving and expectations are increasingly becoming more rigorous. However, 
administrators were badly split on the use of the California Test of Basic Skills (CTBS) and California Assessment Program (CAP) as a method of measuring administrative success. Both systems seem to be highly controversial and unacceptable to a large number of school administrators. A much larger agreement, overall, was found among respondents for the use of program quality review ( $P Q R$ ) as a means of determining administrative effectiveness. The acceptance of this method of assessment may be due to the holistic, multifaceted approach utilized in assessment.

Table 13

Should Administrative Results/Success Be Measured by Administrator Evaluation Form?

\begin{tabular}{lcccc}
\hline Value & Frequency & Percent & $\begin{array}{c}\text { Valid } \\
\text { percent }\end{array}$ & $\begin{array}{c}\text { cumulative } \\
\text { percent }\end{array}$ \\
\hline Strongly agree & 7 & 17.5 & 18.4 & 18.4 \\
Agree & 11 & 27.5 & 28.9 & 47.4 \\
Somewhat agree & 10 & 25.0 & 26.3 & 73.7 \\
Disagree & 9 & 22.5 & 23.7 & 97.4 \\
Strongly disagree & 1 & 2.5 & 2.6 & 100.0 \\
& 2 & 5.0 & & \\
\hline \multicolumn{1}{c}{ Total } & 40 & 100.0 & 100.0 & \\
\hline
\end{tabular}


Table 14

Should Administrative Results/Success Be Measured by student Achievement on CTBS?

\begin{tabular}{|c|c|c|c|c|}
\hline Value & Frequency & Percent & $\begin{array}{l}\text { Valid } \\
\text { percent }\end{array}$ & $\begin{array}{c}\text { Cumulative } \\
\text { percent }\end{array}$ \\
\hline Strongly agree & 2 & 5.0 & 5.0 & 5.0 \\
\hline Agree & 5 & 12.5 & 12.5 & 17.5 \\
\hline Somewhat agree & 14 & 35.0 & 35.0 & 52.5 \\
\hline Disagree & 16 & 40.0 & 40.0 & 92.5 \\
\hline strongly disagree & 3 & 7.5 & 7.5 & 100.0 \\
\hline Total & 40 & 100.0 & 100.0 & \\
\hline
\end{tabular}

Table 15

Should Administrative Results/Success Be Defined by CAP Test Scores?

\begin{tabular}{|c|c|c|c|c|}
\hline Value & Frequency & Percent & $\begin{array}{l}\text { Valid } \\
\text { percent }\end{array}$ & $\begin{array}{c}\text { Cumulative } \\
\text { percent }\end{array}$ \\
\hline Strongly agree & 1 & 2.5 & 2.5 & 2.5 \\
\hline Agree & 5 & 12.5 & 12.5 & 15.0 \\
\hline Somewhat agree & 13 & 32.5 & 32.5 & 47.5 \\
\hline Disagree & 18 & 45.0 & 45.0 & 92.5 \\
\hline Strongly disagree & 3 & 7.5 & 7.5 & 100.0 \\
\hline Total & 40 & 100.0 & 100.0 & \\
\hline
\end{tabular}


Table 16

Should Administrative Results/Success Be Measured by Program Quality Review outcomes?

\begin{tabular}{lcccc}
\hline Value & Frequency & Percent & $\begin{array}{c}\text { Valid } \\
\text { percent }\end{array}$ & $\begin{array}{c}\text { Cumulative } \\
\text { percent }\end{array}$ \\
\hline Strongly agree & 1 & 2.5 & 2.5 & 2.5 \\
Agree & 18 & 45.0 & 45.0 & 47.5 \\
Somewhat agree & 12 & 30.0 & 30.0 & 77.5 \\
Disagree & 9 & 22.5 & 22.5 & 100.0 \\
Strongly disagree & 1 & 2.5 & 2.5 & 100.0 \\
\hline \multicolumn{1}{c}{ Total } & 40 & 100.0 & 100.0 & \\
\hline
\end{tabular}

In the open-ended question of the survey, respondents were asked to list a problem encountered in creating and maintaining an effective school that was not listed on the questionnaire. They were provided one space for written response. Out of 40 possible responses, 19 were given. The responses were hand-tallied to ascertain the top five most frequent responses. A hand-held calculator was used and percentages ending in .5 were rounded to the next highest number (Table 17). 
Table 17

Problems Encountered in Creating and Maintaining an

Effective School

\begin{tabular}{lcc}
\hline \multicolumn{1}{c}{ Problems } & Frequency & Percentage \\
\hline Unrealistic timelines & 5 & 26 \\
Categorization of funding & 5 & 26 \\
Uncommitted principals & 4 & 21 \\
Excessive meetings and paperwork & 3 & 16 \\
Discipline problems & 2 & 11 \\
\hline
\end{tabular}

In summary, I find that the role of the principal has changed in that there are higher organizational expectations as well as greater expectations to perform as the instructional leader of a given school. Site administrators are now, more than ever, being held accountable for student achievement. Principals of schools with large populations of at-risk students or students operating below the $50 \mathrm{th}$ percentile on achievement tests may feel the greatest pressure to perform as administrator effectiveness ratings may be affected.

Survey results suggest a great need for funding and central office support. Administrators were in favor of the time it took them to do teacher supervision and clinical teaching as both are necessary to create an effective school, and it is evident that the site administrator's role 
has changed slightly. As schools become thought of as community schools, the principal becomes responsible for a greater amount of public relation activities as well as the development of creative ways of procuring parent involvement.

Though the role of principal continues to change and administrators are being held accountable to a much greater degree than ever before by way of thorough evaluation, the survey results show that administrators are comfortable with evaluation and therefore with accountability. They, however, were not fully comfortable with using test scores as the criterion for determining site administrator effectiveness. This researcher believes that there are many things to consider when looking at site administrator effectiveness. There are many variables that cannot be controlled by the administrators and should be taken into consideration when looking at test score gains or declines. As educators, we must always keep in mind that we are dealing with the whole child and not just one part of him or her. The same should hold true for the school and community.

Finally, in the open-ended question, a small group of administrator respondents felt hindered in creating an effective school by unrealistic timelines, categorization of funding, lack of principal commitment, excessive meetings and paperwork, and discipline problems. 
Skills and Knowledge for Today's Principals

The third objective of this research is to identify

from the principal's perspective areas of skill and

knowledge that today's principal must possess or actively

pursue in order to be effective instructional leaders.

The respondents were asked: "What kind of knowledge is paramount for today's principal?" and they were provided with six open-ended spaces for written responses. Out of 240 possible responses, 184 were given. The responses were hand tallied to ascertain the six responses most frequently given by the 40 administrator respondents (Table 18). In figuring percentages, a hand-held calculator was used and percentages ending in .5 were rounded to the next highest number.

Table 18

Knowledge and Skills Needed by Today's Principal

Knowledge and skills needed

Race human relations/people skills

Curriculum and supervision

Good communication skills/team building

Budget management

Organizational skills

Effective schools research
Frequency Percentage

21

53

15

38

12

30

11

28

11

28

9

22 
The knowledge and skills listed in priority by site administrators as paramount for today's principals can be divided into four areas. Good team building (people) and communication skills, organizational and budgetary skills, knowledgeable in the areas of curriculum and supervision, and current in effective school research.

The respondents listed many other areas as needs, all pertinent to the job of principal: leadership techniques was Iisted by $8(20 \%)$ of the respondents; community awareness and parent involvement was found to be important by 5 (12\%); time management and stress reduction was listed by 4 (10\%) of the respondents; and knowledge of disciplinary techniques was listed by only 2 principals. All other responses were single entries. A complete list of responses can be found in Table 19.

\section{Additional Questionnaire Summaries}

During the data analysis the researcher found that there were several questions on the survey that did not seem to fit specifically with the three major objectives of this research, yet they were necessary in the development and understanding of the total picture of accountability, the district under study and the perspective of the principals therein.

Respondents were asked: "To what extent should the following people be held responsible for making the 
Table 19

The Knowledge Paramount for Today's Principal

\begin{tabular}{|c|c|}
\hline Arbitration & Behavior modification \\
\hline Budget management & Child growth/development \\
\hline Clinical teaching & Common sense \\
\hline Community awareness & Conflict resolution \\
\hline Curriculum & Decision making \\
\hline Delegation & Discipline techniques \\
\hline District expectations & District procedures \\
\hline Education law/codes & Educational research \\
\hline Evaluation & Goal setting \\
\hline Good communication skills & Hierarchical structure \\
\hline How to solicit help & Human nature \\
\hline Humanism & Impact of home/parents \\
\hline Impact of legislation & Integration information \\
\hline Interpersonal skills & Know Iimitations \\
\hline $\begin{array}{l}\text { Knowledge of and sensitivity } \\
\text { to cultural differences }\end{array}$ & Leadership styles \\
\hline Leadership techniques & Loyalty to program/peers \\
\hline Model curriculum standards & Motivational technique \\
\hline Networking & Organizational contracts \\
\hline Organizational skill & Parent involvement techniques \\
\hline People management skills & Political savvy \\
\hline Problem solving strategies & Program objectives \\
\hline Psychology & Public relations \\
\hline Race human relations & Record keeping \\
\hline Self-awareness & Staff development \\
\hline
\end{tabular}


Table 19 (continued)

State and federal policies

Stress reduction techniques

Tact

Teaching experience

Team building

Time management

World events
Statistical knowledge

Supervision techniques

Teaching techniques

Teaching and learning styles

Test-wiseness

Use of parents/aides

educational process functional: (1) teachers, (2) principals, and (3) central office staff?"

As can be seen in Tables 20 and 21 , there is an even split among the respondents as to teacher and administrator responsibility for making the educational process functional. This researcher believes this polarity of opinions may have been caused by administrators who have seen how hard their teachers work and realize that they, like principals, are up against certain outside variables over which they have no control. It is overwhelming when you think of the sacred trust and responsibility placed in the educators' hands. It appears that half of the respondents did not wish to hold their teachers or themselves responsible for the functioning of the educational process, which tells me that they have no passion for what they are doing. Other respondents appear to believe as I do, that everyone involved in education is, and must be, responsible for making the educational process functional. 
Table 20

Teacher Responsibility for Making the Educational Process

Functional

\begin{tabular}{lcccc}
\hline Value & Frequency & Percent & $\begin{array}{c}\text { Valid } \\
\text { percent }\end{array}$ & $\begin{array}{c}\text { Cumulative } \\
\text { percent }\end{array}$ \\
\hline Strongly agree & 3 & 7.5 & 7.5 & 7.5 \\
Agree & 8 & 20.0 & 20.0 & 27.5 \\
Somewhat agree & 9 & 22.5 & 22.5 & 50.0 \\
Disagree & 14 & 35.0 & 35.0 & 85.0 \\
Strongly disagree & 6 & 15.0 & 15.0 & 100.0 \\
\hline \multicolumn{1}{c}{ Total } & 40 & 100.0 & 100.0 & \\
\hline
\end{tabular}

Table 21

Principal Responsibility for Making Educational Process

Functional

\begin{tabular}{lcccc}
\hline Value & Frequency & Percent & $\begin{array}{c}\text { Valid } \\
\text { percent }\end{array}$ & $\begin{array}{c}\text { cumulative } \\
\text { percent }\end{array}$ \\
\hline Strongly agree & 3 & 7.5 & 7.5 & 7.5 \\
Agree & 8 & 20.0 & 20.0 & 27.5 \\
Somewhat agree & 9 & 22.5 & 22.5 & 50.0 \\
Disagree & 14 & 35.0 & 35.0 & 85.0 \\
Strongly disagree & 6 & 15.0 & 15.0 & 100.0 \\
\hline \multicolumn{1}{c}{ Total } & 40 & 100.0 & 100.0 & \\
\hline
\end{tabular}


An analysis of variance was completed by gender in an effort to ascertain whether female principals as a group held significantly different opinions than male principals. Results indicate one area where differences were apparent at the .05 level significance. Female school administrators more strongly agreed that the principals should be held responsible for making the educational process functional (Table 22). Though male and female respondents were evenly matched, 20 in each grouping, male responses were much less in unison, while female responses were more tightly grouped. The outcome data, therefore, are reliable and trustworthy and not a chance happening.

Table 22

To What Extent Should Principals Be Held Accountable for Making the Educational Process Functional?

\begin{tabular}{lcccc}
\hline Sex of principals & Mean & SD & F value & Significance \\
\hline Female & 1.05 & 0.22 & 4.57 & .0389 \\
Male & 1.75 & 1.45 & & \\
\hline
\end{tabular}

Table 23 shows the responses regarding the responsibility of the central office staff for making the educational process functional. The same kind of split that appeared between the teachers and principals is evident with the central office staff. This split is surprising, because 
many principals have stated the need for greater central office support in creating effective schools, which seems to mean accepting greater responsibility for the educational process and the way it functions. Central office personnel who most often come into contact with schools begin with those handling budgets, staffing, area operations managers, and assistant superintendents. Again, however, it appears that half of the respondents wish to hold no one responsible for making the process work while the other half agrees that all parties must work cooperatively to ensure the effectiveness of the process because everyone shares the responsibility for implementation.

Table 23

Central office Staff Responsibility for Making Educational Process Functional

\begin{tabular}{|c|c|c|c|c|}
\hline Value & Frequency & Percent & $\begin{array}{l}\text { Valid } \\
\text { percent }\end{array}$ & $\begin{array}{c}\text { Cumulative } \\
\text { percent }\end{array}$ \\
\hline strongly agree & 3 & 7.5 & 7.5 & 7.5 \\
\hline Agree & 8 & 20.0 & 20.0 & 27.5 \\
\hline Somewhat agree & 9 & 22.5 & 22.5 & 50.0 \\
\hline Disagree & 14 & 35.0 & 35.0 & 85.0 \\
\hline strongly disagree & 6 & 15.0 & 15.0 & 100.0 \\
\hline Total & 40 & 100.0 & 100.0 & \\
\hline
\end{tabular}


Principal responses were split in half in exactly the same manner, 50\% agree and 50\% disagree, on all five parts of the following question: "The accountability movement has resulted from: (7) poor parent school communication; (8) lack of committed, qualified teachers; (9) lack of committed, knowledgeable site administrators; (10) new board and central office administration; and (11) Bill Honig, State Superintendent of Education?" The researcher believes, as do half the respondents, that all of the above are factors in part causing the accountability movement. I, however, wonder what the other $50 \%$ of the respondents believed the cause of the movement to be as they chose none of the above.

However, an analysis of responses to items 7-11 when divided into ethnic subgroups indicates two areas of significance at the .05 level as variance was analyzed among groups. Black administrators had a much lower mean score than white, Hispanic, or Asian group administrators, which showed that they were more in agreement with the statement that the accountability movement has resulted from the lack of committed, knowledgeable site administrators than other groups. This view ties in well with effective schools research, which states that effective principals are the primary cause of effective schools (Table 24).

White respondents somewhat agreed that the accountability movement was directly related to Bill Honig, state Superintendent of Education; however, blacks and Hispanics 
showed greater agreement and Asians showed strong agreement (Table 24).

Variance within groups was found at the .02 level on responses as to whether site administrative results/success should be defined and measured through Program Quality Review (a state directed evaluation process based on the effective school research). The researcher labeled groups whites and nonwhites. The nonwhite group was comprised of black, Hispanic, and Asian groups. Nonwhites agreed with the statement while whites seemed to somewhat agree with the statement (Table 25).

In areas of the survey requiring written response, principals were asked to give three characteristics of an instructional leader. Responses were combined and a composite was made utilizing the approximate wording used by the principals to describe instructional leadership characteristics from the principal's perspective. One principal's concise comments summarized instructional leadership perfectly when the person wrote:

An instructional leader is committed to the instructional program and to children. He or she communicates effectively with staff, students, parents and community; has the ability to plan, organize, monitor and follow through with duties and responsibilities. Knowledgeable about programs, he or she monitors implementation and gives constructive feedback to site personnel. 
Table 24

The Accountability Movement in the District Has Resulted from the...

\begin{tabular}{|c|c|c|c|c|c|}
\hline Question & Ethnic group & Mean & SD & F value & Significance \\
\hline $\begin{array}{l}\text { 9. Lack of committed, knowledgeable } \\
\text { site administrators }\end{array}$ & $\begin{array}{l}\text { Black } \\
\text { White } \\
\text { Hispanic } \\
\text { Asian }\end{array}$ & $\begin{array}{l}2.17 \\
3.68 \\
3.71 \\
4.00\end{array}$ & $\begin{array}{l}1.17 \\
1.14 \\
1.11 \\
0.00\end{array}$ & 3.22 & 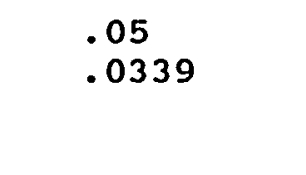 \\
\hline $\begin{array}{l}\text { 11. Bill Honig, state superintendent } \\
\text { of Education }\end{array}$ & $\begin{array}{l}\text { Black } \\
\text { White } \\
\text { Hispanic } \\
\text { Asian }\end{array}$ & $\begin{array}{l}1.50 \\
2.58 \\
1.57 \\
1.00\end{array}$ & $\begin{array}{l}1.22 \\
1.21 \\
0.79 \\
0.00\end{array}$ & 3.12 & $\begin{array}{l}.0385 \\
.05\end{array}$ \\
\hline
\end{tabular}

Table 25

Site Administrative Results Should Be Defined and Measured...

Question Ethnic group Mean SD F value Significance

$\begin{array}{llllll}\text { 20. Through use of program quality } & \text { Whites } & 2.96 & .89 & 5.76 & .0214 \\ \text { review which includes effective } & \text { Nonwhites } & 2.33 & .62 & & .01\end{array}$
schools/integration monitoring 
All of the responses given were pertinent to the role of instructional leader. The responses that remained most in my mind in regards to creating an atmosphere that is conducive to student learning and realizing the truly effective school are those that when combined are aligned with educational research. From the principal's perspective, an instructional leader must be willing to take risks to accomplish the best for kids. Be compassionate, positive, and able to work with and through all types of people. Be visible, flexible, innovative, energetic, and hold high expectations for self and staff. The list of characteristics continues. Each is as important to the role of instructional leader as the next. Table 26 lists the characteristics of instructional leadership. As no two responses were alike, all responses listed are single responses.

Respondents were asked what the consequences should be for professional educators, including administrators, who are unable to achieve agreed upon results in student learning after they have been held accountable by their supervisors. The 40 principals generated 61 written responses which were analyzed for like responses. Nine principals believed that retraining, inservice, and mandated official review courses should be required in assisting those administrators to achieve agreed upon results in student learning, while 6 believed that they should seek other employment. Five responses suggested that support and 
Table 26

Question 21: Characteristics of an Instructional Leader

Able to establish clear lines of responsibility/delegation of authority

Able to laugh at him/herself

Able to work with all types of individuals

Accessible

An effective clinical supervisor

A participatory leader

Committed to students and school goals

Communicative

Compassionate and positive

Competent

Creative

Energetic

Enthusiastic

Flexible

Innovative

Involved

Knowledge of curriculum and instruction across grade levels Knowledgeable of current educational research

One who gives feedback to staff

One who has high expectations for curriculum outcomes One who has tenacity

One who has the ability to develop long/short range plans one who has the ability to identify constraints 
Table 26 (continued)

One who has the ability to interpret and implement site programs

One who has the ability to make sound decisions

One who has the ability to motivate and persuade

One who has the ability to rally people to one goal

One who has the ability to rectify problems

One who holds high expectations for staff and self

One who models expected behavior

One who monitors, encourages, and enables

One who provides constant monitoring and evaluation

One who provides good inservice opportunities

One who uses clear judgment

organized

Positive change agent

Positive role model

Practical and realistic

Resourceful

Supportive of and listens to staff

Tough skinned

Visible

willing to take risks to accomplish the best for kids Works with and through people 
resources be given to assist in goal attainment, while 5 believed that removal from administration was the answer to the problem of low student achievement. Mentioned as possible consequences was the need for individual counseling (2), return to the classroom (3), and demotion (2). Most of the consequences were positive in nature and assumed that the administrator was capable of rehabilitation while others were punitive and direct as can be seen in Table 27.

Not all respondent answers are listed in Table 27 due to the fact that they were not phrased as consequences. A few of the principals stated the difficulty in predicting student achievement and suggested that other variables be considered in administrator evaluation since a principal should not be held responsible or accountable for things beyond his or her control. Another felt that only when administrators are allowed to pick their staff and support personnel should they be held responsible and consequences applied for lack of student achievement.

The last question on the questionnaire asked respondents what they would need to change in order to make their site an even more effective school. Responses were written and greatly varied as each school is unique and site needs vary and can be dependent on many different variables, i. e., special funding, personnel or a restructuring school attempting to better its student program through change. Knowing that elementary and secondary schools have different 
Table 27

Question 23: Suggested Consequences for Professional Educators Including Administrators

Who Are Unable to Achieve Agreed Upon Results in student Learning

\begin{tabular}{lc}
\hline \multicolumn{1}{c}{ Consequence } & Frequency \\
\hline Required retraining and official review courses & 9 \\
Counseled into another career or employment & 6 \\
Determine reasons for lack of achievements/lend support/resources & 5 \\
Removal from administrative position & 5 \\
Provide assistance in identifying areas of weakness & 3 \\
Return to the classroom & 3 \\
Change in assignment for reassignment & 3 \\
Provide individual counseling & 2 \\
Dismiss if support and help produce no change & 2 \\
Demote & 2 \\
Counseled into frontiers where skills match the job \\
Give ineffective rating and place on probation \\
Send to california school Leadership Academy
\end{tabular}


Table 27 (continued)

Consequence

Frequency

Place them in line positions rather than field

Lessen direct responsibility for students and more for curriculum

Change objectives to a more realistic level

1

Provide more incentives to job share/professional leaves

1

Develop an action plan

1

Close monitoring of site programs from direct supervisor

Implementation of a less than effective staff development plan

1

Hold central office accountable for lack of decentralization 
needs, this researcher was both pleased and surprised that analysis of responses echoed all of the needs that had been expressed by principals as areas of concern for some time. Many areas, of course, would require large sums of money to implement since they require employment of additional personnel or salary advancement and most districts are not financially equipped to fully rectify these needs.

Each respondent listed several areas where changes were needed. The tallying of responses was difficult because in looking for like responses, wording was important. There are five patterns that seemed to emerge and show the changes desired by the principals. Ten site administrators in some way stated the need for more on-site support personnel, i. e., counselors, vice principals, or resource teachers, while 7 desired an increase in site budgets. Parent support and participation was important, with 6 principals stating this as a need. Five principals listed the reduction of paperwork and 4 saw staff development as an area of need. Three principals wanted to select their own staff, while another 3 either wanted to do away with tenure or find an easier way to deal with ineffective teachers. Finally, 2 administrators felt the need for safer school environments and 2 would have to change low teacher expectations in order to make their schools more effective. Table 28 is a list of responses with the approximate wording of the respondents. 
Table 28

Question 24: What Would You Have to Change in order to Make Your site an Even More

Effective School?

A vice principal for schools with over 600 students

All elementary schools need an out of classroom resource teacher or administrative intern

All sites need full time counselors to handle routine disciplinary problems

Assistance in stress reduction

Better central office support and consistency

Freedom to set site priorities at site level

Full time nurse or more nurse time

Improved maintenance of facilities

Increase teacher participation in decision making

Increase parent support and participation

Increase school budget and discretionary funding

Less meetings and reports that take away from instructional leadership time

Money for on site teacher inservice 
Table 28 (continued)

Money for pre/post school year site planning and goal setting

More time on site

More walls for loft schools/open classrooms

More recognition for efforts

Principal selection and recruitment of staff

Principal selection of vice principal, site counselor and head secretary

Raise student self-esteem

Raise teacher expectation for some groups of children

Reduce paperwork

Reduced class size

select site staff

Site security for a more safe and orderly environment

The elementary staffing formula to be improved to the same as secondary

There is a need for an easier way to remove ineffective or marginal teachers 


\section{Interview Summaries}

The principal of six schools and six key central office staff members, including the superintendent and two board members, were interviewed. The 40-minute to one-hour interviews centered chiefly on the questions in the survey which had been modified for interview purposes.

Events Leading to the Accountability Movement Within the District

Several respondents believed that the public's dissatisfaction with educators and the state reform legislation were accountability catalysts while others saw the movement as a cyclical process which takes place every 10 years. Also mentioned as possible cause of the accountability movement within the district was the desegregation court order and polarization of the board and administration. The public attitude about education and educators was also seen as an accountability movement catalyst.

one respondent stated:

It's the perception of some individual families that things aren't right or perfect with their children and how they are developing as human beings. This perception has impacted the school. If things aren't right, look at school instead of at the family for solutions.

Another respondent stated: 
In an urban setting, families, single parent or families with both parents working, are involved in activities outside work and school. They don't have time to deal with problems, but they feel the school does, and they want quick results.

\section{Drawbacks Encountered in Implementing Changes Associated} with the Effective Schools Research

When asked what drawbacks have been encountered in implementing changes, some central office personnel stated that increased paperwork (both district related and state mandated) were drawbacks to implementation along with the negative attitudes of some people in and out of the schools. The collective bargaining process was also mentioned as a drawback. One of the participants stated, "Now you have to negotiate every change in programs." The principals believed that lack of central office support, paperwork and priority demands on their time were spreading them too thin and were drawbacks to implementing changes associated with the effective schools research.

One respondent suggested, "With change comes the need to re-establish trust and familiarize oneself with new procedures and demands." Another responded:

The principal must value the changes being made, and I don't. I must see the benefit for the child in the changes. The philosophy of management by objectives as a sole means of management leads to inhuman management 
of teachers and administrators because the outcome is stressed and not the process of how to attain the objective. The process is the part promoting growth.

\section{Definition of an Instructional Leader}

The interviewees were asked: What is your definition of an instructional leader? Why? The answers given to this question were very much the same as those given in response to survey questions. The central office administrators and principals painted a picture of an instructional leader as one who influences students, staff and community to strive for quality education. His or her mission is to ensure that every student makes progress from september to May, i. e., a month's growth for every month of instruction. The leader sets the tone that all children can learn, has vision, knowledge and the ability to communicate, motivate, and mobilize people toward the desired goal. The reasons that the respondents gave these characteristics for instructional leaders varied, but all of them had one common focus, student success.

One respondent stated:

An instructional leader is one who knows what the expectations are, the vehicles needed to implement the expectations, and curriculum. It is not necessary to know everything about curriculum, but they are current on research, they seek and use current information with staff. He or she brings community, staff, and students 


\begin{abstract}
along with them. The leader sets realistic goals, assesses those implementing the goals as well as those who are learning. He/she helps all staff members with assessments and with the review of those assessments. Another respondent suggested:

In some ways an instructional leader is like a spiritual leader. He or she sets the tone for the school and should be able to transmit the feeling that he or she could take over a class and model a demonstration lesson for a teacher if needed.
\end{abstract}

\title{
Time Spent by Principals Observing Teachers and Planning
} Curriculum

This question, how much time do principals spend observing teachers' planning and curriculum, was asked only of the site administrators. No specific length of time was really given for teacher observation or curriculum planning; however, all administrators mentioned that they followed district guidelines and contractual timelines for teacher observations. Clinical teaching methods were a part of the evaluation process. Over three quarters of the principals interviewed mentioned that they made regular classroom visitations or brief walk-throughs. Elementary principals spoke of grade level meetings being held to discuss curriculum and implementation. Grade level meetings were used as a time for teachers to share innovations and for goal and expectation setting. The principals often attended these 
meetings. At the secondary level, departmental and department chair meetings took place.

The Impact of the Accountability Movement on Principals Respondents were asked: What impact has the accountability movement had on principals? Some principals felt that the movement had caused them to become a "jack of all trades." Others stated that the movement had affected the principalship in a negative way and believed there was no trust in school administrators as professional, caring, dedicated people who were interested in bettering the administration of the school. These administrators suggested that Maslow's theory of the hierarchy of man's needs was not being addressed for principals in the area of self-esteem. However, the majority of the principals interviewed believed that the accountability movement was a positive movement and created a much needed awareness of educational research. The principals understood that as a district and nation, educators had only scratched the tip of the accountability iceberg, so to speak, and that children needed advocates. The role of the administrator was to ensure that effective, good instruction takes place through supervision and other monitoring strategies. As one interviewee put it, "To be the instructional leader and make things happen for kids, you must get out and monitor your school. Run your school." 
Administrators who had been with the district during the former superintendent's tenure stated that there had been no district agenda articulated and that test scores and student achievement were never discussed nor were the superintendent's or board's yearly goals. That has been changed and on each quarterly visit made by the area operation managers or assistant superintendents, the discussions at meetings are aimed at board goals and the visitors engage in classroom observations.

Central office administrators realized that the onset of the movement originally created a great deal of anxiety and resistance to change. However, they noted that with some acceptance of the movement, a revitalization process has taken place for many principals and it has given them the opportunity to extend themselves. The central office respondents also indicated that for some site administrators, those especially who had come into the principalship through the "good old boys" network, the movement has seemed threatening. They believed that the accountability movement has helped to make good principals better and mediocre principals better. One respondent stated, "With the movement came the realization that some principals may not have been prepared to accept the role, but for others it's opened doors and brought autonomy." 
Problems Principals Encounter with the Implementation of the Superintendent's objectives

Respondents were asked: What problems are principals encountering with the implementation of the superintendent's objectives? Why? Various responses were presented by the 12 respondents. Several felt that improving student achievement to the 50th percentile was difficult at best when taking into account high student mobility, the high number of new teachers hired in a large district along with tenured teachers who are resistant to change. Lack of facilities was another drawback to implementation. Communication was a continual problem due to the complexity of the district. The superintendent agreed with these statements, but he also was optimistic, realizing that acclimation to change takes time. "The sheer number of objectives, the short timelines, and lack of wiggle room produces more pressure to cope with. On the plus side, there is new excitement and satisfaction when progress can be seen as a result of the effort being made."

Changes in the Role of the Principal in the Last Three Years When asked how has the role of the principal changed in the last three years, again, answers varied but were cohesive between principals and central office administrators. The realities of the changes in the role of the principal seemed to be the same for both groups of respondents. Several stated that things were a lot looser 
before, referring to the previous superintendent's administration, and went on to say that now many administrators feel there is too much monitoring and too much paperwork. others felt that the principal was being asked to create curriculum and write programs and they are also held more directly accountable to the community than ever before. Central office administrators stated that there was no longer a dichotomy between leader and manager. Today's principal must be both. Today's principals were more aware of the research on good teaching practices, put greater responsibility on the inservice staff, and were given more accountability for budget allocation and spending. School administrators were expected to take more risks and be accountable for them. They had to write specific student achievement goals and then act to achieve student academic gains. They were given the opportunity to deviate from accepted district programs, i. e., reading, but were held accountable for student outcomes if they did sponsor different programs.

The central office administrators opined that the children were progressively harder to teach because of societal and family changes.

Kind of Knowledge or Skill Paramount for Today's Principal

When asked what kind of knowledge or skill is paramount for today's principal and why, all of the respondents were in basic agreement. Today's administrators need good public 
and human relations skills, team building skills and knowledge of budget and statistics. Other necessary skills and attributes are flexibility, being a risk taker and innovator, and being sensitive to the cultural differences that children bring to school. Paramount is that today's principals be instructional leaders who set the tone for learning and change, be decision makers who can handle routines and deal with compromising situations, and realize that "the buck stops with the principal."

\section{Participant Responsibility for the Educational Process} Respondents were asked: To what extent should each participant in the educational process be held responsible for the results? There was unanimous agreement that all participants in the educational process should be held responsible to the highest extent for results. One respondent nicely summed up the statements of all respondents when she said, "Everyone is to work his/her hardest and anyone who isn't working that hard is doing the children a disservice." Another respondent stated: I feel that I am personally responsible for my areas of responsibility. Everyone should feel this way. When you feel this way you don't mind being held responsible for results to the highest extent because you already hold yourself responsible. 
Holding Participants Responsible for the Educational Process

Respondents were asked: To whom should each participant in the educational process be responsible? some respondents said that the first responsibility for the educational process and its results is to one's self and is evidenced in the attainment of results or goals that have been set. Other respondents believed that the principal should be responsible to the teachers, students, community, and the profession. The principal has the charge of keeping the profession in good standing. Teachers are the model for the students, and the principal is the model for the public. A smaller number of respondents also stated that the superintendent, school board, and the business world at large are the people to whom educators should be responsibie as they are the consumers of our student products.

Defining and Measuring Results

Respondents were asked: How are results to be defined and measured? Several themes emerged from the answers: measurable objectives should be written and taught; test scores, attendance patterns, dropout rates, and school climate should be used as methods of defining results. One respondent stated, "One way of defining and measuring results is by looking at the product you send home everyday." 


\section{Determining Participants' Contribution}

Respondents were asked: How will each participant's contribution be determined? Most respondents had no answer to this question. Some administrators stated that it takes a coordinated group effort to meet the educational objectives in schools. However, a small subgroup noted that performance evaluation plans may serve as major indicators. Other methods of systematic evaluations, $i$. e., test scores, school climate, could also help determine each participant's contribution.

\section{Consequences for Educators}

Respondents were asked: What should the consequences be for educators who are unable to achieve agreed-upon results in student learning? There was unanimous agreement that persons unable to achieve agreed-upon results in student learning should be provided with indepth inservice and ensured due process. Counseling on performance items requiring improvement should be provided and necessary assistance given. The bottom line, however, was demotion, retirement and/or employment in another area of education other than administration.

\section{Merit Pay for Teachers}

When asked what is their view of merit pay for teachers, the school administrators saw many problems with how students would be assigned to various teachers and with staff morale. One principal respondent stated that: 
I can't assign all students to the classrooms of merit pay teachers, yet I believe that parents have the right to expect the best for their children. In addition, I have yet to implement an inservice program where in one hour a teacher has taught others and as a result had better teaching from all teachers. The central office administrators suggested a career ladder approach to higher pay rather than assessing individual teachers for merit pay. Superintendent Payzant went one step further when he stated, "I think that we should reward an entire staff for an effective school, from the custodian to teacher. Perhaps we should reward grade level groups; however, we have collective bargaining restraints on such things."

Merit Pay and Senate Bill 813

Respondents were asked: Is there a possibility of merit pay and Senate Bill 813 widening the gap between principals and teachers? Why or why not? The majority of the respondents gave a simple answer of "no." Two respondents believed that merit pay could widen the gap between principals and teachers, depending on the maturity of the staff and the principal.

\section{Making Site Administrators More Effective}

Respondents were asked: What would you have to change in order to make site administrators more effective? The following themes emerged: use of the county assessment 
center as a staff development exercise rather than as an evaluation exercise; bringing in well trained vice principals to replace principal retirees; realization that a school administrator is often only as good as his or her staff; principals need to be listened to so that their needs can be met. Time needs to be secured which does not detract from students or staff to allow administrators to meet in manageable groups for more indepth staff development and sharing of ideas.

One respondent stated:

You have to bring in the vice principals who have had a tremendous amount of training to replace principal retirees. The principals that I have worked with who are less than effective are not tuned into change and have been around the longest. Principals need time to focus on effectiveness.

Another respondent said:

The process of becoming a site administrator is important and a good cross-section of administration is encouraged. Good teachers should be encouraged to stay teachers. Administrators are often only as good as their staffs. We need to provide adequate support to principals. Take a look at who makes it into the ranks of principal, and we need to listen to principals and find out their needs.

Much information from the principal's point of view has been derived as a result of this study along with that of 
key central office staff. The next chapter will provide the reader with food for thought as conclusions are drawn, summary and implications provided. 
CHAPTER V

SUMMARY, CONCLUSION, AND RECOMMENDATIONS

\section{Summary}

This study is an investigation of the accountability movement and its impact on selected principals in a large southern California school district. Though many studies have centered on the school district in question, few studies, if any, have had principal or site impact as a primary focus.

\section{The Purpose}

The major purposes of this study are:

1. To ascertain the impact of the educational accountability movement on the behavior of selected principals in the San Diego Unified School District from 1983-1986.

2. To determine what changes the accountability movement has had on the role of principal.

3. To identify from the principal's perspective areas of skill and knowledge that today's principals must possess or actively pursue in order to be effective instructional administrators.

Many educational theorists and practitioners saw the accountability movement as one of national concern for 
student achievement and academic literacy which was a direct attempt to improve educational inadequacies. The review of the literature describes the accountability movement in terms of the effective schools movement in which the site administrator plays a key role as visionary, instructional leader and change agent possessing high expectations for self, students, staff and $\equiv l l$ others connected with his or her site. Much of the research centered on characteristics of effective achieving schools and characteristics of effective principals. The researcher is interested in delineating knowledge paramount for today's site leaders and aspiring leaders. Therefore, this study was designed to gather information from both site administrators and key central office staff inclusive of district superintendent, selected assistant superintendents and board members.

\section{Research Design}

The procedure utilized to gather information in this study focused on survey questionnaire and interview methodologies. The researcher constructed the survey mailing list of 50 school administrators representing approximately one-third of the district's schools by means of a systematic random sample. These principals responded to 24 questions, some open ended and others rated on a Likert-like scale instrument. Out of 50 questionnaires mailed, 40 (80\%) of the principals responded. Thirty elementary schools were sent surveys and 26 principals 
responded. Ten middle/junior and 10 senior high school principals were sent surveys with a return of 9 for middle/junior and 5 for senior high schools. The student enrollment of both elementary and secondary schools ranged from the mid hundreds to well over 1,000 students with some schools above the 2,000 range.

Nearly half (19) of the survey respondents had been site administrators for 1-5 years, 6 had been on site for 610 years and 15 had been principals for more than 10 years. The ethnic breakdowns of principals surveyed were as follows: 4 blacks, 25 whites, 7 Hispanics and 4 Asian Pacific Islanders. Of the 40 principal respondents, 20 were male and 20 were female.

\section{Results}

The following analyses represent the results of the study as they relate to the research objectives.

1. The first objective of this study is to ascertain the impact of the educational accountability movement on the behavior of selected principals from the principals' perspective so that information could be provided on the expectations for school leadership and change. This information gives insight into how principals viewed and coped with the accountability movement and changes.

Most principals saw the movement as beneficial and believed that the movement for effective schools had indeed had a great impact on their behavior as principal. The 
major impact of the movement on the principals was the continual increase of responsibility and accountability for student achievement.

2. The second objective of the research is to determine what role changes principals had experienced due to the accountability/effective schools movement.

The respondents reported that site administrators were under greater pressure to perform due to higher organizational expectations. The role of principal is that of jackof-all-trades. The principal is everything to everybody at the school. The principal must be a good instructional leader, because responsibility for student achievement rests with the site manager. Along the same lines, parent and community participation is extremely important; therefore, the site administrator must also be a proactive liaison between the community and school. The principal is also expected to work more with the less-than-effective teachers and be knowledgeable about current educational research. The principal is responsible for implementing current reforms to improve the school.

3. The third purpose of this research is to identify areas of skill and knowledge paramount for today's effective instructional leader.

The respondents reported that today's principal must possess or actively pursue good race/human relations and people skills because a major part of the job is working with and through people. A thorough understanding of 
curriculum and supervision is very important if the instructional leader is to successfully provide inservice, monitor and evaluate teacher and student performance as well as provide assistance to the less-than-effective staff members. Communication and team building skills facilitate positive school climate and site cohesion. Budget skills, organizational skills and knowledge of effective schools research were also in the top six responses of the respondents.

\section{Conclusions and Discussion}

Based on the results of this study, the researcher drew the following conclusions.

1. The accountability movement within the district under study is due to several reasons, including the following three major factors. The first, mentioned in background data, began with the then existing superintendent and what appeared to be a lack of commitment to the integration program for court-identified minority segregated schools and the board's dissatisfaction with managerial and leadership skills. The second was the Nation at Risk report released in 1981 by the National Commission on Excellence in Education, which called for immediate and rigorous education reform. Lastly, changes in societal expectations, needs and parental dissatisfaction with public schools caused the accountability movement to explode on the scene. 
Principals participating in this study were given five areas, excluding those previously mentioned, as possible causes of the accountability movement. Respondents were badly split as to the cause of the accountability movement within the district and no one significant belief as to the movement's cause emerged. All factors, lack of parent communication, committed qualified teachers, committed knowledgeable administrators, new board and central office administration, and Bill Honig, state Superintendent of Education, were, in part, causing change to occur.

2. Though the movement for effective, accountable schools has significantly impacted the behavior of principals within the study by way of higher organizational expectations, the majority of these principals (73\%) were comfortable with being evaluated using administrative evaluation forms which were based on the attainment of site and district goals and objectives. The goals and objectives of the principals were developed in collaboration with central office managers who were, in some cases, assistant superintendents. Surveyed principals, however, were not comfortable with the use of student achievement test scores as the major criterion for determining site administrator effectiveness unless all variables, including those outside the principal's control, were also taken into consideration. This problem may suggest that school districts and communities may have to look at school outcomes in a more 
holistic manner, much in the same way as schools deal with the whole child.

Central office staff members were somewhat aware of the need to broaden the administrator evaluation process. If the process is to become holistic, objectives will need to center on more than mere test scores. They may need to extend objectives to a greater degree to encompass parent education and involvement as a means of empowering parents and assisting them to feel more comfortable in educational settings.

Assistance and funding may need to be provided to develop and implement objectives focused on the coordination of centralized social services, $i$. e., counseling, medical and housing needs provided for children and families. In this way, the school would have some control over some of the many variables that affect a child's readiness to learn. since parents contact most schools for assistance in these areas already, coordination of services to parents would help in better meeting the needs of students.

3. The areas of skills and knowledge that respondents believed to be paramount for today's principal are closely aligned with the literature supporting the need for principal instructional leadership which encompasses being knowledgeable of curriculum, instruction, supervision, staff development needs and evaluation. Good interpersonal communication skills and organizational and budget management skills continue to be as important for today's 
principal as they were to school administrators of the past. In addition, team building skills, knowledge of research, community awareness and parent involvement skills were also found to be important, perhaps due to recent state and federal funding mandates for parent involvement and participation in school program and budgetary recommendations.

However, based on analysis of principals' responses, the only conclusion that can be drawn is that the skills needed for today's principal are closely aligned with those of yesterday's principal. It may be that today's stressors are greacer, necessitating greater emphasis on some skills and less on others. Important to the leaders in the $1990 \mathrm{~s}$ may be the ability to be flexible in one's thinking and one's willingness to change paradigms. Interview data gathered from the principals and central office staff suggest that proactive leaders will need the skills and knowledge necessary to be visionary, risk takers and innovators if change is to be effected in our schools.

4. Respondents were overwhelmingly child centered and committed to children. This world view became evident in their responses of suggested consequences for educators and administrators who are unable to achieve agreed upon results in student learning after they had been held accountable by their immediate supervisors. Strong feelings emerged and approximately one-fourth $(23 \%)$ of the respondents believed that ineffective peers should be required to take retraining 
and official review courses. When suggested consequence areas were combined, 23 respondents, approximately 57\%, believed that those who had been provided assistance but continued to produce ineffective student outcomes should be removed from administrative positions in which they were directly responsible for children and/or counseled into other areas of education or another profession.

These findings suggest that the majority of principals are sincere in their efforts to educate their clientele. Personal responsibility is being taken by these principals for student outcomes and they won't tolerate those who are less committed. This may signify a change or new breed of principal as the "good old boy" system breaks down. Peer pressure to perform may become an unofficial future trend. Child centeredness also suggests the need for collegiality. Principals of achieving schools could be asked to strategize with principals of low achieving schools. When children are the focal point, much is possible.

5. In creating an effective school, administrators' needs were school specific and varied. Several stated the need for additional support personnel, others desired an increase in site budgets or the ability to staff, and a reduction in daily paperwork. These were the major drawbacks to the creation of effective schools. Other drawbacks were the need for safer school environments, low teacher expectations, and the need for an easier way of dealing with the ineffective teacher. All responses were on target and 
expressed the needs that many principals have had for some time.

Many of the areas listed pose dilemmas for the school principal because they keep the principals from spending the majority of their day in classrooms. Monitoring programs, teacher observation and provision of instructional leadership should be the greatest portion of an administrator's day. The day, however, can be spent taking care of discipline problems, paperwork, dealing with parent complaints related to teacher expectations or lack of classroom discipline and documenting the less-than-effective teacher. Greater central office support was also an area of need. Though schools have their own individual needs, the principals expressed many common needs which, due to district budgetary constraints, may be impossible to implement but may be worth discussing with central office staff. 6. Regardless of race, gender, educational grade level hierarchy or number of school programs, the principals appeared to be in agreement in their responses to the majority of the questions on the survey questionnaire. The same is true of those who were interviewed. The needs and wants voiced by the school administrators were overwhelmingly the same. My assumption that schools with larger student populations and more complex programs would tend to answer questions in the same manner or feel greater pressure to perform than schools with smaller populations was rejected. I found that while larger schools and those with 
numerous educational programs and funding sources may be somewhat more complex, the basic school needs which empower and enable principals remain constant.

\section{Recommendations for Further Study}

1. Future research should examine the accountability movement and areas of change within the district under study from 1986 to 1991 to further add to the overall picture of the changes that have taken place within this district. This study showed conclusively that change brought with it pressure to perform and higher expectations. The next issue, however, is to determine the long-term outcomes of the accountability movement.

2. This study was limited to site and central office administrators. Using the same questionnaire, the study might be expanded to include perspectives of teachers in order to find out how they view the accountability movement and its impact on them: the pressures they feel related to student academic achievement, their thoughts on the teacher evaluation process and the delineation of needed support which would enable teachers to run more effective classrooms, evidenced by greater student outcomes.

3. Future studies might also examine the effects of accountability/effective schools movement on students: changes in curriculum, student expectations, and graduation requirements to ascertain the impact of the accountability movement from the students' point of view. 


\section{Concluding Remarks}

Accountability is a fluid and fast moving field which may be culturally and socially bound depending on our society and its wants and needs, be they real or perceived. This study began with the researcher viewing changes as they began to take place in a large urban school district. Accountability may take different forms, but it will always be with us. Knowing this and that people are generally resistant to change because of its impact on them, the study was undertaken to find out exactly how principals had been impacted by the changes. In carrying out the study I found conclusively that site administrators have indeed been impacted by the effective schools movement and, therefore, are being held accountable for student outcomes as never before.

Though threatening at first, the accountability movement has proved to be positive in that it has set higher organizational expectations and provided an arena in which site administrators must stretch themselves realizing that the status quo is not good enough nor is it acceptable. Children, our most precious resource, will someday be tomorrow's citizens. It is up to site administrators everywhere to ensure to their full ability that the children in their charge reach their full potentials, are literate, and able to function in a competitive and complex society. If they are to succeed they must educate their staffs and enlist community and parental support. Communities ask a 
great deal of their principals, it is true; however, they ask no more than the principals are capable of.

In the words of Boyer (1983):

Without good schools, none of our problems can be solved. People who cannot communicate are powerless. People who know nothing of their past are culturally impoverished. People who cannot see beyond the confines of their own lives are ill-equipped to face the future. It is in the public school that this nation has chosen to pursue enlightened ends for all its people. And this is where the battle for the future of America will be won or lost. (p. 31) 


\section{REFERENCES}

Abbott, J. (1988, May/June). Accountability for California's public schools. Thrust for Educational Leadership, 7, 8-10.

Alkin, M. C. (1972) . Accountability defined evaluation: Comment. Los Angeles: University of California, Center for the Study of Evaluation.

Amor, D., Conry-Osequerd, P., Cox, M., King, N., McDonnell, L., Pascal, A., Pauley, E., \& Zellman, G. (1976). Analysis of the school preferred reading program in selected Los Angeles minority schools. Ios Angeles: Rand.

Austin, G. R. (1979, October). Exemplary schools and the search for effectiveness. Educational Leadership, 37, 10-12.

Babbie, E. R. (1973). Survey research methods. Belmont, CA: Wadsworth.

Backstrom, C. H., \& Hursh, G. D. (1963). Survey research. Evanston, IL: Northwestern University Press.

Benjamin, R. (1981, March) . The rose in the forest: A city principal who beats the odds. Principal, 60, 1015.

Benveniste, G. (1985, Fall) . The design of accountability systems. Educational Evaluation and Policy Analysis, Z, 261-280.

Blumberg, A., \& Greenfield, w. (1960). The effective principal: Perspectives on school leadership (2nd ed.). Boston: AlIYn and Bacon.

Blumberg, A., \& Greenfield, W. (1980). The effective principal. Boston: Allyn and Bacon.

Borg, W. R., \& Gall, M. D. (1983). Educational research (4th ed.). New York: Longman. 
Bossert, S. T. (1971). Tasks, group management, and teacher control behavior: A study of classroom organization and teacher style. School Review, 85, 552-565.

Boyer, E. L. (1988, April 27). A demographic portrait of America's future students. Education Week, 7,31 .

Bratlie, M. (1987). The conversion of teachers: Principal influence and teacher autonomy. Pullman: Washington state University. (ERIC Document Reproduction Service No. ED 302 877)

Brookover, W. G., \& Lezotte, I. W. (1979). Changes in school characteristics coincident with changes in student achievement. East Lansing: Michigan state University. (ERIC Document Reproduction Service No. ED 181 005)

Brophy, J. (1979). Teacher behavior and its effects. Journal of Teacher Education, 71, 733-750.

Brophy, J., \& Enertson, C. (1974). Process product correlations in the Texas teacher effectiveness study: Final report. Austin: University of Texas.

Brown, P. (1990). Accountability in public education. San Francisco: Far West Laboratory for Educational Research.

Buffie, E. (1989). The principal and leadership. Bloomington, IN: Phi Delta Kappa Educational Foundation.

Burns, D., \& Iindner, B. (1985, October). Why the states must move quickly to assess excellence. Educational Leadership, 43, 18-24.

California Commission on the Teaching Profession. (1985). Who will teach our children? Sacramento: Author.

Carlin V. Board of Education. (1967). Case No. 303800. Superior court of California, County of San Diego.

Carlin V. Board of Education. (1977, March 9). Memorandum decision and order. Case No. 303800. Superior court of California, County of San Diego.

Carlin V. Board of Education. (1979, September 20). Charge to the integration task force, 1979-80 school year. Case No. 303800. Superior Court of California, County of San Diego. 
Carlin v. Board of Education. (1980, December 2). Order re: Integration plan of 1980-81. Case No. 303800 . Superior Court of California, County of San Diego.

Carlin v. Board of Education. (1981, August 3). Memorandum of intended decision. Case No. 303800. Superior Court of California, County of San Diego.

Carnegie Corporation of New York, Ford Foundation, Johnson Foundation, United States Department of Education, \& New York Times Foundation. (1986). Tomorrow's

teachers. East Lansing: Michigan state University.

Carnegie Forum on Education and the Economy. (1986). A nation prepared: Teachers for the 21 st century. New York: Carnegie Corporation.

Cawelti, G. (1980). Focusing instructional leadership on improved student achievement. Anaheim, CA: National Institute of Education. (ERIC Document Reproduction Service No. ED 184 241)

Clark, D., Lotto, L., \& McCarthy, M. (1980). Factors associated with success in urban elementary schools. Phi Delta Kappan, 61, 467-470.

Cohen, E., Miller, R., Bredo, A., \& Duckworth, K. (1977). Principal role and teacher morale under varying organizational conditions. Stanford, CA: Center for Research Development in Teaching.

Coleman, J., Campbell, E., Hobson, C., McPartland, J., Mood, A., Weinfeld, F., \& York, R. (1966). Equality of educational opportunity. Washington, DC: U.S. Government Printing office.

Coleman, J. S., Hoffer, T., \& Kilgore, S. (1982). High school achievement: Public, Catholic and private schools compared. New York: Basic Books.

Colvin, T. (1981, September 29). Halfaker waivers on superintendent vote. San Diego Union, p. Al.

Crawford V. Board of Los Angeles. (1976). Case No. 17 Cal. 3d. 280, 285. Superior court of California, county of Los Angeles.

Cunningham, L. L. \& \& Nystrand, R. O. (1986). New forms of citizen participation in school affairs. Washington, DC: The Urban Coalition. 
Dobbert, M. I. (1982). Ethnographic research: Theory and application for modern schools and societies. New York: Praeger.

Dwyer, D. C. (1984, February). The search for instructional leadership: Routines and subtleties in the principal's role. Educational Leadership. 41, 32-37.

Edmonds, R. (1979, October). Effective schools for the urban poor. Educational Leadership, 37, 20-24.

Fischer, C. W., Filby, N. N., Marliane, R. S., Cahan, L. S., Dishaw, M. M., Moore, J., \& Berliner, D. C. (1978). Teaching behaviors, academic learning time, and student achievement: Final report on Phase III-B, beginning teacher evaluation study. San Francisco: Far West Laboratory for Educational Research and Development.

Gersten, R., \& Carnine, D. (1982). Focusing on support functions. Eugene: University of Oregon, Center for Educational Policy and Management Perspective.

Gillmore, J. (1981, September 26). Demotion by school board. San Diego Tribune, p. Al.

Glatthorn, A. A., \& Newberg, N. A. (1983). Instructional leadership: Four ethnographic studies of junior high school principals. Philadelphia: University of Pennsylvania.

Good, T. I., \& Grouws, D. A. (1977) . The Missouri mathematics effectiveness project: An experimental study in fourth-grade classrooms. Journal of Educational Psychology, 71, 355-362.

Goren, P. D. (1984). Organizations and change: A case study of the administrative reorganization of the San Diego Unified School District. Austin: University of Texas.

Greenblatt, R. B., Cooper, B. S., \& Muth, R. (1984, February). Managing for effective teaching. Educational Leadership, 41, 57-59.

Gretcho, S., \& DeMont, R. (1980, April). The principal makes the difference. Paper presented at the annual meeting of the National School Boards Association, San Francisco.

Gross, S., \& Furey, S. (1987). Study of the changing role of the elementary principal. Rockville, MD: Montgomery County Public Schools, Department of Educational Accountability. 
Howell, B. (1981, January) - Profile of the principalship. Educational Leadership, 39, 333-336.

Huberman, A. M., \& Miles, M. B. (1983). Innovation up close: A field study in 12 school settings. Andover, MA: The Network.

Huberman, A. M., \& Miles, M. B. (1984). Qualitative data analysis: A source book of new methods. Beverly Hills, CA: Sage.

Huff, S., Lake, D., \& Schaalman, M. (1982). Principal differences: Excellence in school leadership and management. Boston: McBer.

Hunt, J. (1989, October). Incipient studies of schoolbased decision groups. Florida. (ERIC Document Reproduction Services No. ED 311 5432)

Iannaccone, I. (1967) . Politics in education. New York: Center for Applied Research in Education.

Jencks, C., Smith, M., Ackland, H., Bane, M., Cohen, M., Gintis, D., Heyns, B., \& Michelson, S. (1972). Inequality: A reassessment of the effect of family and schooling in America. New York: Basic Books.

Jennings, L. (1989, January) . School yard gun spree leaves 6 dead 30 injured. Education Week, $8,18$.

Jentz, B., \& Wofford, J. (1979) - Leadership and learning: Personal change in a professional setting. New York: McGraw-Hill.

Johnson, J. M. (1978) - Doing field research. New York: The Free Press.

Kirst, J., Nyquist, E., \& James, H. T. (1982, February 23). Final report to the Honorable Frankl in B. Orfield, Superior Court No. 24, San Diego, California.

Lessinger, L. M. (1970). Every kid a winner: Accountability in education. New York: Simon and Schuster.

Lipham, J. M. (1982). Effective principal, effective school. Reston, VA: National Association of Secondary School Principals.

Lopez, F. M. (1970). Accountability in education. Phi Delta Kappan, 52, 231-233.

Lurie, E. (1971). How to change schools. New York: Random House. 
Manasse, A. L. (1984, February) . Principals as leaders of high-performing systems. Educational Leadership, 4I, $42-46$.

Marcus, A., Wellisch, J., MacQueen, A., Duck, G. A., \& Lee, D. R. (1976) - Administrative leadership in a sample of successful schools from the national evaluation of the Emergency School Aid Act. Santa Monica, CA: System Development Corporation. (ERIC Document Reproduction Service No. ED 125 123)

Melendez, M. (1991, January). Minorities as majority. Educational Leadership, 20, 4 .

Merriman, H. O. (1970). The columbus school profile. Columbus, $\mathrm{OH}$ : Columbus School District.

Murnane, R. (1981). Interpreting the evidence on school effectiveness. Teachers College Record, 83, 19-35.

National Academy of Education, Commission on Education and Public Policy \& Commission on Reading, \& National Institute of Education. (1985). Becoming a nation of readers. Washington, DC: U.S. Department of Education.

National Commission on Excellence in Education. (1983) . A nation at risk: The imperative for educational reform. Washington, DC: U.S. Government Printing office.

Nixon, R. M. (1970) - Compilation of presidential documents. Education Reform Weekly, $\underline{6}, 304-414$.

Olson, L. (1991, February). Proposals for private-school choice reviving at all levels of government. Education Week, 10, 22.

Payzant, T. (1982, October 8). Proposed organization, San Diego City Schools: Concept paper. San Diego: San Diego City Schools.

Pennsylvania State Department of Public Instruction. (1983). Phase I findings. Harrisburg, PA: Author.

Peters, T. J., \& Waterman, R. H., Jr. (1982). In search of excellence. New York: Harper and Row.

Reeves, M. S. (1988, April 27). Self interest and the common weal: Focusing on the bottom half. Education Week, I, 31.

Reitzug, U. (1989, April). Principal-teacher interactions in instructionaliy effective and ordinary schools. Urban Education, 24, 38-58. 
Rost, J. C. (1991). Leadership for the twenty-first century. New York: Praeger.

San Diego City Schools. (1982, February 16). Report of task force to study district administrative reorganization. San Diego: Author.

Schuman, H., \& Presser, S. (1981). Questions and answers in attitude surveys: Experiments on question form wording and context. New York: Academic Press.

Sergiovanni, T. (1987) - The principalship: A reflective practice perspective. Boston: Allyn \& Bacon.

Shoemaker, J., \& Fraser, H. (1981). What principals can do: Some implications from studies on effective schooling. Phi Delta Kappan, 63, 178-182.

Smith, A. G. \& Louis, K. S. (1982) . Multimethod policy research: Issues and applications. American Behavioral Scientist, $\underline{26}(1)$.

Smith, L. M. (1978). An evolving, logic of participant observation, educational ethnography and other case studies. In I Schulman (Ed.), Review of research in education (Vol. 6). Itasca, IL: F. E. Peacock.

Snider, W. (1989, September). Survey confirms rapid speed of effective schools. Education week, 9,4 .

Stronge, J. (1988, May) - The elementary school principalship: A position in transition? Principal, 67, 5 .

Sudman, S., \& Bradburn, N. M. (1982). Asking questions. San Francisco: Jossey-Bass.

Sykoff, L. S. (1988). The emergence of the middle school in independent education. Unpublished doctoral dissertation, University of San Diego, California.

Task Force to study the organizational structure in san Diego Unified School District. (1981, March 17). organization study of the San Diego Unified School District. San Diego: San Diego City Schools.

Thompson, T. (1991, February). Thompson endorses hiring private practice teachers. Education Week, 10, 21.

Vincent, D. (1984, June). The effects of Proposition 13 on California schools: Five years later. Thrust for Education Leadership, 13, 16-19. 
Wilson, S. (1977). The use of ethnographic techniques in educational research. Review of Educational Research, 47, 245-265.

Witkins, B. R. (1984). Assessing needs in educational and social programs. San Francisco: Jossey-Bass.

Wolcott, F. (1973). The man in the principal's office: An ethnography. New York: Holt, Rinehart and Winston.

Wynne, E. (1972). Politics of school accountability: public information about public schools. Berkeley, $C A$ : McCutchan.

Zurhellen, H. (1987). Educational accountability within the context of academic freedom. Paper presented at the annual meeting of the American Educational studies Association, Chicago. 
APPENDIX A

PRINCIPAL QUESTIONNAIRE

\section{PRINCIPAL QUESTIONNAIRE}

Directions: This questionnaire is concerned with the effective schools and accountability movements and their impact on the principalship. Please circle the appropriate number for questions 1-20. The questionnaire will take ten to fifteen minutes to complete.

A. Sex: $M_{----}$

B. School Level: _— Elementary

_ Middle/Junior Figh

- Secondary

C Number of years as a principal:

$0-5$

6-10

more than 10

D. Number of teachers on your site:

\begin{tabular}{ll}
$-0-12$ & \\
$-13-24$ & $41-55$ \\
$25-40$ & $-66-65$ \\
\hline & 66 or more
\end{tabular}

E Name the school program in which your school participates (i.e., School Improvement, Chapter I, etc.):

1.

2

3.

4. 


\section{PRINCIPAL QUESTIONNAIRE}

$$
\begin{aligned}
& 1=\text { Strongly Agree } \\
& 2=\text { Agree } \\
& 3=\text { Somewhat Agree } \\
& 4=\text { Disagree } \\
& 5=\text { Strongly Disagree }
\end{aligned}
$$

To what extent should the following people be held responsible for making the educational process functional?
1. Teachers
$\begin{array}{lllll}1 & 2 & 3 & 4 & 5\end{array}$
2. Principals

$\begin{array}{lllll}1 & 2 & 3 & 4 & 5\end{array}$
3. Central office staff

$\begin{array}{lllll}1 & 2 & 3 & 4 & 5\end{array}$

To what extent has the impact of the accountability movement affected you as a principal?
4. Higher organizational expectations
$\begin{array}{llllllll}\text { and pressure to perform. } & 1 & 2 & 3 & 4 & 5\end{array}$
5. Being held accountable for student

$\begin{array}{lllllll}\text { achievement (i.e., CIBS scores) } & 1 & 2 & 3 & 4 & 5\end{array}$

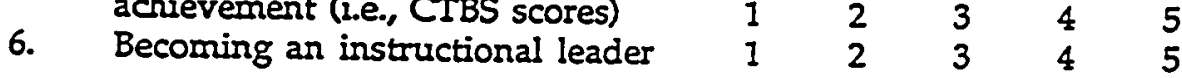

The accountability movement in our district has resulted from the following:

7. Poor parent/school communication $1100 \begin{array}{llllll} & 2 & 3 & 4 & 5\end{array}$

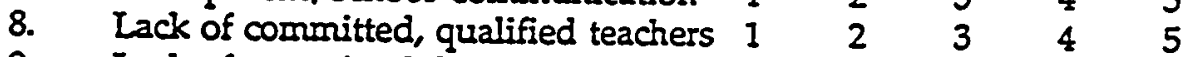

9. Lack of committed, knowledgeable site administrators

10. New board and central office administration

11. Bill Fonig State Superintendent of Education

$\begin{array}{lllll}1 & 2 & 3 & 4 & 5\end{array}$

$\begin{array}{lllll}1 & 2 & 3 & 4 & 5\end{array}$

$\begin{array}{lllll}1 & 2 & 3 & 4 & 5\end{array}$ 
The problems encountered in creating or maintaining an effective school are:

12. Lack of central office support and

13. funding

13. Teacher observation/clinical teaching too time consuming

14. Uncooperative teachers or teachers needing technical assistance

15. Lack of parent participation

16. Others (list below)

$\begin{array}{lllll}1 & 2 & 3 & 4 & 5 \\ 1 & 2 & 3 & 4 & 5 \\ 1 & 2 & 3 & 4 & 5 \\ 1 & 2 & 3 & 4 & 5\end{array}$

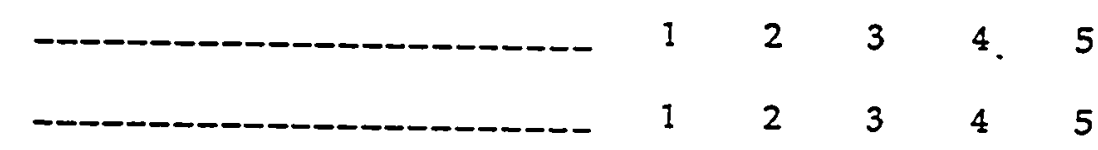

Site administrative results should be defined and measured.......

17. through the use of the administrator's evaluation form.

18. through student achievement on CTBS tests.

19. through use of California Assessment Program (CAP).

20. through Program Quality Review which includes effective schools and integration monitoring.

$\begin{array}{lllll}1 & 2 & 3 & 4 & 5 \\ 1 & 2 & 3 & 4 & 5 \\ 1 & 2 & 3 & 4 & 5 \\ 1 & 2 & 3 & 4 & 5\end{array}$

21. Give three characteristics of an instructional leader?
a.
b.
c. 
22 What kind of knowledge is paramount for today's principal?

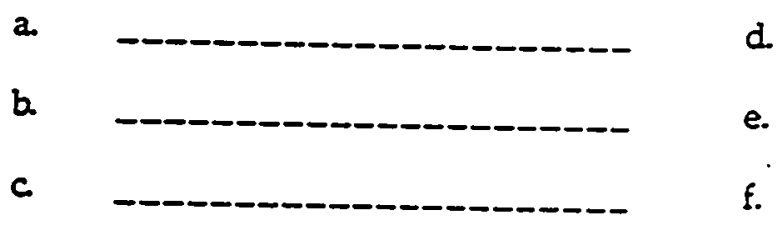

d.

e.

f.

23. What should the consequences be for professional educators (induding administrators) who are urable to achieve agreed upon results in student learning after they have been held accountable by their supervisors?
a.
b.
c

24. What would you have to change in order to make your site an even more effective school?
a.
b.

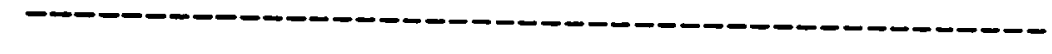
c
d.
e. 


\section{APPENDIX B}

IETTER OF TRANSMITTAL TO FIELD TEST PARTICIPANTS

April 5, 1987

Dear

I am a doctoral student at the University of San Diego. I have just completed the development of the administrative survey questionnaire that I.plan to use in assessing the impact of the accountability movement on principals in the San Diego Unified School District, which, is my topic.

Before sending out a blanket mailing, however, I am in need of feedback on the questionnaire. Please take a moment to look over the enclosed materials, cover letter/questionnaire, and to complete the instrument following the directions as written. Feel free to write constructive comments on the questionnaire so that I may make needed improvements on the survey. All feedback will be greatly appreciated. Please return the completed questionnaire with your feedback via school mail by April 15, 1987.

Thank you for your time and support.

Sincerely,

DIANETTE MITCHELL

Vice Principal

Valencia Park Elementary School 


\title{
APPENDIX $C$
}

\section{LETTER OF TRANSMITTAL TO PRINCIPAIS}

\author{
June 3, 1987
}

\section{Dear Colleague:}

With the permission of the San Diego Unified School District and the - University of San Diego, I am currently researching as my dissertation topic, the effective schools and accountability movement within our district.

The purpose of this research is to ascertain the effects of this movement on the site principal and principalship as a whole. As a site administrator, I have observed and participated in the many changes that have taken place within our district. The principalship, as we once knew it, is now in a state of change.

The data collected from the attached questionnaire will be highly beneficial to current and aspiring administrators and will delineate skills pertinent to today's administrator.

In order for this research to be completed, your support is needed. Please take 15 minutes out of your busy day to complete this survey and return it to Dianette Mitchell at Valencia Park School on or before June 17, 1987.

\section{Anorimity Guaranteed!}

\author{
Sincerely,
}

DLANETTE MITCHELL

Vice Principal

Valencia Park Center for

Academics Drama and Dance 


\section{APPENDIX D}

\section{INTERVIEW QUESTIONS}

\section{INTERVIEW QUESTIONS}

1. What events led to the accountability movement within our district?

2 What drawbacks or problems have been encountered in implementing the many changes associated with the findings of effective schools research?

3. What is your definition of an instructional leader? Why?

4. How much time do you spend observing teachers' planning curriculum?

5. What impact has the accountability movement had on principals? Why?

6. What problems are principals encountering with implementing the superintendent's objectives? Why?

7. How has the role of principal changed in the last three years?

8. What kind of knowledge or skill is paramount for today's principal? Why?

9. To what extent should each participant in the educational process teacher, principal, and central staff administrator - be held responsible for results?

10. To whom should they be responsible?

11. How are results to be defined and measured? (By administrator's evaluation form?)

12. How will each participant's contribution be determined?

13. What should the consequences be for professional educators (including administrators) who are unable to achieve agreed upon results in student learning after they have been held accountable by their supervisors?

14. What would you have to change in order to make site administrators more effective? 